\title{
TRTaKadeMi
}

ISSN 2149-9446 | Cilt 06 | Sayı 12 | Mayıs 2021 | Dijital Hayat ve Etik

\section{Algoritmalar, Yapay Zekâ ve Makine Öğrenimi Ekseninde Gazetecilik Etiği: Uluslararası Akademik Dergilere Yönelik Bir İnceleme}

\author{
Bahar KAYIHAN* - Bilge NARIN** \\ Demet FIRAT*** - Feyyaz FIRAT****
}

Öz

\begin{abstract}
Algoritmalar pek çok alanda olduğu gibi gazetecilikte de kullanılır hâle gelmiştir. Ancak bu durum, etik sorunları da beraberinde getirmiştir. Ayrıca algoritmalar geliştikçe etik sorunlar artmaya devam etmektedir. Bu nedenle bu çalışmada algoritma etiği üzerine odaklanılmıştır. Bu kapsamda gazetecilik alanıyla ilgili önde gelen üç dergi olan Digital Journalism, Journalism Studies ve Journalism \& Mass Communication Quarterly'de 2019 ve 2020 yıllarında yayımlanmış algoritmalarla ilgili çalışmalar nitel içerik analizi yöntemi ile incelenmiştir. Alanda önde gelen bu dergilerde algoritma etiğine ne şekilde değinildiğini açığa çıkarmak hedeflenmiştir. Bu doğrultuda, makalelerin odaklarına, araştırmada kullanılan kuram/kavramlara, çalışmaların yöntemlerine, örneklemlerine, çalışmaların gerçekleştirildiği ülke ya da ülkelere ve algoritma etiğine yönelik bulgularına odaklanılmıştır. Sonuç olarak, gazetecilik alanında önde gelen bu dergilerde algoritmalara ilişkin çalışmalara fazla yer verilmediği, ayrıca çalışmaların çok azında etik sorunlara değinildiği açığa çıkmıştır. Algoritma etiğini araştıran sınırlı sayıda çalışmada ise algoritmalara dayalı etik ihlallerin, insanların tehlike altında hissetmeleri ya da suçsuz yere yargılanmaları gibi çeşitli sorunlara neden olabileceği ifade edilmiştir. Ayrıca bu çalışmaların etik sorunların çözümüne yönelik çeşitli yasal düzenlemeleri, makine öğrenimi teknolojisinin kullanımını, gerektiğinde insan kontrolünü ve algoritma seçimleri hakkında kullanıcıların bilgilendirilmesini önerdiği anlaşılmıştır.
\end{abstract}

\section{Anahtar Kelimeler: Algoritma, Algoritma Etiği, Dijital Gazetecilik, Etik, Gazetecilik}

\footnotetext{
* Dr. Öğr. Üyesi, Ankara Hacı Bayram Veli Üniversitesi, İletişim Fakültesi, Gazetecilik Bölümü, bhrkayihan@gmail.com

**Doç. Dr., Ankara Hacı Bayram Veli Üniversitesi, İletişim Fakültesi, Gazetecilik Bölümü, narinbilge@gmail.com

***Arş. Gör., Ankara Hacı Bayram Veli Üniversitesi, İletişim Fakültesi, Lisansüstü Eğitim Enst. demetfirat14@gmail.com **** Arş. Gör., Ankara Hacı Bayram Veli Üniversitesi, Iletişim Fakültesi, Gazetecilik Bölümü, feyyazfiratt@gmail.com
}

\section{Araştırma Makalesi}

Geliş Tarihi: 20.03.2021

Revizyon Tarihi: 28.04.2021

Kabul Tarihi: 24.05.2021 


\title{
TRTAKaDeMi
}

ISSN 2149-9446 | Volume 06 | Issue 12 | May 2021 |Digital Life and Ethics

\section{Journalism Ethics on the Axis of Algorithms, Artificial Intelli- gence and Machine Learning: A Review of International Aca- demic Journals}

\author{
Bahar KAYIHAN - Bilge NARIN \\ Demet FIRAT - Feyyaz FIRAT
}

\begin{abstract}
Algorithms have become used in journalism, as in many other fields. However, this situation has brought ethical problems with it. In addition, ethical problems continue to increase as algorithms evolve. Therefore, this study focused on algorithm ethics. In this context, studies on algorithms published in 2019 and 2020 in Digital Journalism, Journalism Studies and Journalism \& Mass Communication Quarterly, which are three leading journals in the field of journalism, were examined. For this, qualitative content analysis method was used. It is aimed to reveal how algorithm ethics are mentioned in these leading journals in the field. In this direction, the focus of the articles, the theory/concepts used in the research, the methods of the studies, the samples, the country or countries where the studies were carried out, and the findings of algorithm ethics were focused. As a result, it has been revealed that these leading journals in the field of journalism do not have much coverage on algorithms, and that only a few of the studies address ethical issues. In a limited number of studies examining algorithm ethics, it has been stated that ethical violations based on algorithms can cause various problems such as people feeling in danger or being prosecuted innocently. Also, it is revealed that, these studies suggest various legal regulations, the use of machine learning technology, human control when necessary, and informing of users about algorithm choices for the solution of ethical problems.
\end{abstract}

Keywords: Algorithm, Algorithm Ethics, Digital Journalism, Ethics, Journalism 


\section{Giriş}

Illetişimde veri elde etme, yayma ve işleme olasılı̆ı̆ı ırtıran yapay zekâ uygulamalarının kullanımının yaygınlaşması, internete geniş çaplı erişimin sağlanması sonucunda dijital ortamların artş̧ıla aynı zamana denk gelmektedir. Hemen her sektörü etkisi altına alan yapay zekâ teknolojileri otomatik haber yazımının yanı sıra veri arama işlemlerini, sınıflandırmaları, enformasyon işleme ve filtrelemeyi otomatikleştirerek gazetecilerin habercilik rutinlerini de değiştirmeye başlamıştır (Túñez-Lopez vd., 2019: 1413-1414). Gazeteciliğe uygulanan algoritma formülasyonları, enformasyonu önceliklendirebilmekte, sınıflandırabilmekte ve filtreleyebilmektedir. İzleyicileri analiz etmek, kapsayıc konuları belirlemek ve veri tabanlarında elde edilen enformasyona göre otomatik metinler yazmak için algoritmalardan yararlanılmaktadır (Anderson, 2012; Carslon, 2015). Bu anlamda algoritmalar, haber toplama ve yazma sürecini kolaylaştıran bir rol oynamaktadır.

Henüz teknolojik gelişiminin erken bir aşamasında olmasına rağmen algoritmalar, gazetecilik alanında yapılandırılmış büyük verilerle otomatik haber oluşturma ve kişiselleştirilmiş haber içerik akışları sağlama gibi uygulamalarla her geçen gün daha fazla kullanılır hâle gelmektedir. Gazetecilikte haber üretiminde ve dağıtımında algoritmaların kullanımını önümüzdeki yıllarda da önemli ölçüde artacağı öngörülmektedir (Lewis vd., 2018: 14). Öte yandan gazetecilik alanında algoritmaların kullanımının giderek artması, yeni etik sorunları da beraberinde getirmektedir. Bu durum, çağdaş gazetecilik çalışmalarının da algoritmaların gazetecilikteki kullanımına ve bu kullanım pratiklerinin neden olduğu etik sorunlara odaklanmasına neden olmaktadır.

Bu çalışmanın amacı algoritmaların gazetecilikte yarattı̆ı belirli bir etik soruna odaklanmak yerine, sorun alanlarının genel bir tespitini yaparak alandaki öncü çalışmaları incelemektir. Bu kapsamda SClmago verilerine göre 2019 yııında en üst sırada yer alan gazetecilik alanıyla ilgili üç dergi olan Digital Journalism, Journalism Studies ve Journalism \& Mass Communication Quarterly'nin 2019 ve 2020 yılarındaki tüm sayıları incelenerek algoritmalar ve gazeteciliği konu alan çalışmalarda etik konusunun izi sürülmüştür. Toplamda 2019 ve 2020 yıllarında yayımlanmış 497 makale incelenmiştir. Konu ile doğrudan ilgili olduğu tespit edilen 31 makale ise detaylı bir şekilde ele alınmıştı. Algoritmalar ve gazetecilik etiği ile ilgili güncel araştırmaların tematik bir analizinin yapılması yoluyla konunun mevcut dijital gazetecilik çalışmalarındaki güncel, metodolojik ve teorik eğilimlerinin belirlenmesi hedeflenmiştir. Böylece algoritmalarla ilgili araştırma gündeminin örüntüleri, dijital gazetecilik etiğiyle ilişkili olarak tartşsmaya açılmıştır. 


\section{Algoritma Toplumu ve Algoritma Etiği}

Algoritmaları temel olarak, sonuca ulaşmak için izlenen bir dizi yol olarak tanımlamak mümkündür. Dolayısıyla yapay zekânın öncesinde de algoritmaların varlığından söz etmek mümkündür. Yapay zekâ ise yazılımların, faaliyetleri canlılara benzer şekilde yapabilmeleri anlamına gelmektedir. Kökeni oldukça eskiye dayanan, mantıksal ve kontrole dayalı bileşenler olan algoritmalar, yapay zekânın gelişimi ile birlikte yalnızca bir kod bileşeni olmaktan çıkarak tekno-sosyolojik bir konu hâline gelmiştir. Verinin hiç olmadığı kadar arttı̆̆ ve enformasyon toplumu açısından kullanılabilir hâle geldiği mevcut dönemde algoritmalar bu verileri işlemeye ve dönüştürmeye başlamıştır. Böylece önceleri yalnızca bilgisayar biliminin inceleme nesnesi olan algoritmalar, günlük hayatın rutin bir parçası olmuştur ve günümüz toplumu bir algoritma toplumuna dönüşmüştür. Algoritmaların öğrenebilirliğini ifade eden makine öğrenimi ya da derin öğrenme gibi kavramlar ise algoritma toplumunun son aşamasını oluşturmaktadır.

Yapay zekâ artık toplumsal hayat kolaylaştıracak birçok önemli fayda sağlamaktadır. Insanlar yorulurken makineler yorulmamakta ve insanlar gibi yıl boyunca tüm gün çalışabilmek için molalara ve içeceklere ihtiyaç duymamaktadır. Akıllı telefonlar; insanların yemek, giyim ve barınaktan sonraki dördüncü ihtiyacı hâline gelmiştir. Bunun bir nedeni ise yapay zekâya dayalı algoritmalardır. Haritalar, yemek siparişi uygulamaları, çevrim içi alışveriş uygulamaları gibi uygulamalarla insan hayat kolaylaşmıştır. Ayrıca çok sayıda tıbbi uygulama da yapay zekâyı kullanmaya başlamıştır. Bunun da ötesinde, algoritmaya dayalı tıbbi prosedür test sistemi, yapay zekânın olağanüstü gelişim parçasıdır (Jameel vd., 2020). Algoritmaların tıp alanındaki mevcudiyeti, insan hayatını kolaylaştırmaktan da öteye giderek insan hayatını uzatan ve kalitesini artıran bir konuma sahip olmuştur.

Bunların da ötesinde algoritmalar, hayatımızı sessizce yapılandırmaktadır. Algoritmalar yalnızca arama sonuçlarını ve çevrim içi gördüğümüz reklamları belirlemede rol oynamamakta, aynı zamanda kimin terörist olduğunu, etnik kökenlerimizi, ne ödeme yapacağımızı, ne okuduğumuzu, kredimizi, dolandırılmamızı, bir başkanlık seçiminde nasıl hedef alındığımızı, kovulmamızı ve şartlı tahliye edildiysek veya mahkûm edildiysek tüm bunları bilebilmekte ya da belirleyebilmektedir. Bu amaçla algoritmalar, eğilimleri belirlemek ve tahminlerde bulunmak için veri kümelerini incelemektedir. Bu belirsiz veri kümelerini anlamlandırmak için ise daha iyi, daha hızlı ve her yerde bulunan algoritmalara güvenilmektedir (Martin, 2019: 836). Ayrıca algoritmalar toplumsal düzen üzerinde belirleyici olmaya başlamıştır. Böylece bilginin nasıl tüketildiğini ve gerçekliklerin nasıl inşa edildiğini şekillendirmektedir. Çeşitli günlük yaşam aktiviteleri ve medya tüketimi 
- örneğin çevrim içi haber seçimi, müzik, film ve video eğlencesi tüketimi - arama motorları ve tavsiye sistemleri aracılığıyla otomatik algoritmaya dayalı seçim ile şekillendirilmektedir (Just ve Latzer, 2017: 239). Toplumsal hayat açısından bu kadar belirleyici hâle gelen algoritmaların ise kaçınılmaz bir şekilde, beraberinde olumsuzlukları da getirdiğini söylemek mümkündür. Bu sorunların merkezinde ise etik ihlaller yer almaktadır.

Algoritmaları etik açıdan değerlendiren çalışmalar çeşitlidir (bkz. Raymond ve Shackelford 2013; Parmar ve Freeman 2016; Ananny 2016; Leben 2018; Kearns ve Roth 2019). Bu çalışmaların hepsi farklı etik sorunlara yoğunlaşıyor olsa da hepsi algoritmaların etik sorunlara neden olduğunu kabul etmektedir. Mittelstadt ve diğerlerine göre (2016: 4-5), algoritmalar alt ayrı etik soruna yol açabilmektedir. Epistemik ya da normatif endişelere neden olan bu etik sorunlar; algoritmaya dayalı sonuçsuz, anlaşılmaz ve yanlış yönlendirilmiş bulgular, haksız sonuçlar, dönüştürücü etkiler ve verinin izlenebilirliğidir. Algoritmalar sonuçsuz bulgulara ulaşabilmektedir çünkü çıkarımsal istatistikler ve/veya makine öğrenimi tekniklerini kullanarak işledikleri verilerden sonuçlar çıkardıklarında, olası ancak kaçınılmaz olarak belirsiz bilgi üretebilmektedirler. Algoritmalar anlaşılmaz bulgulara neden olabilmektedir ve yanlış yönlendirilmiş bulgulara ulaşabilmektedir çünkü algoritmalar verileri işler ve bu nedenle tüm veri işleme türleri tarafindan paylaşılan, yani çıktının hiçbir zaman girişi aşamayacağı bir sınırlamaya tabidirler. Ayrıca algoritmalar haksız sonuçlara ve olumsuz anlamda çeşitli dönüştürücü etkilere neden olabilmektedir. Bunun nedeni, algoritmaların hem dünyayı nasıl kavramsallaştırdığımızı hem de toplumsal ve politik organizasyonu nasıl değiştirdiğimizi etkileyebilmesidir. Son olarak algoritmalar, izlenebilirdir ve bu da veri güvenliği ve mahremiyet açısından büyük bir sorun oluşturmaktadır.

Algoritmalar nedeniyle, kullanıcıların kişisel verilerinin ne kadar güvende olduğu tartışmalı bir konu hâline gelmiştir çünkü algoritmaya dayalı yapay zekâ uygulamaları, verileri toplarken ve işlerken bir taraftan da bu verilerin gizliliğini ihlal edebilmektedir. Algoritmaya dayalı pek çok uygulama, kullanıcıların dijital ortamdaki izlerini takip edebilmektedir. Bunun da ötesinde kullanıcıların kişisel verileri, reklam verenler ile onların izinleri olmaksızın paylaşılarak kullanıcılar birer metaya dönüştürülebilmektedir. 
Şekil 1. Algoritmalara Yönelik Alt Tür Etik Kaygı. Kaynak: Mittelstadt, 2016: 4.

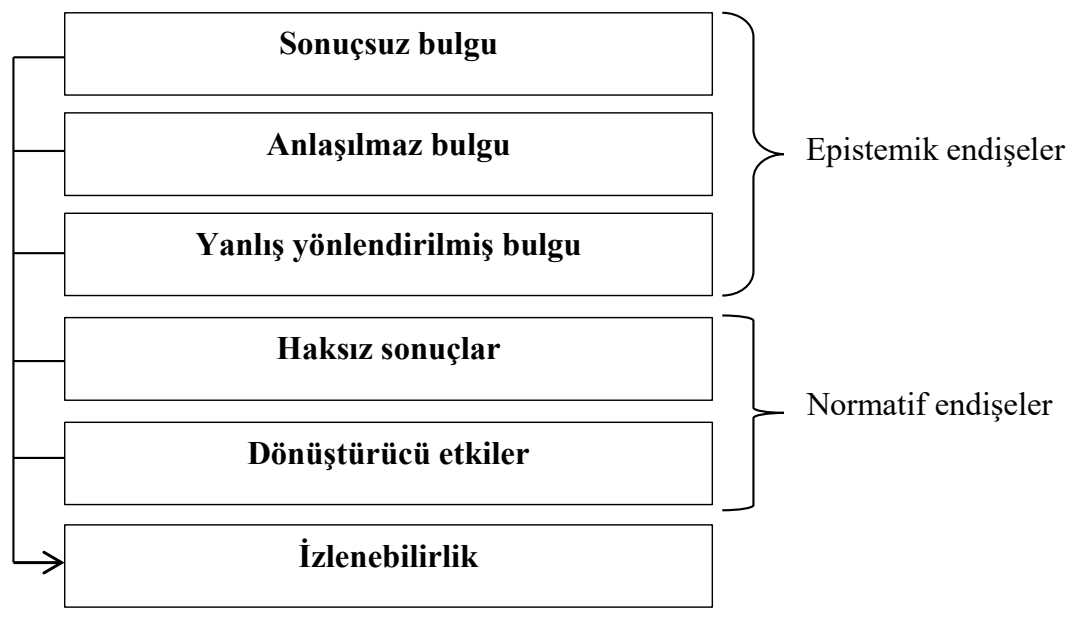

Algoritmalar yalnızca bulguları nedeniyle ya da izlenebilirliğe sebep olmaları nedeniyle etik ihlallere neden olmamakta, aynı zamanda önyargılara, mevcut sistemdeki etik sorunları pekiştirmeye, enformasyonun asimetrik dağılımına da yol açabilmektedir. Gillespie'ye göre (2014: 179) algoritmaların değerlendirmelerini adil ve doğru kabul etmek, nesnel ve hatadan muaf olduklarını düşünmek hataIıdır. Aksine algoritmalar, önyargılardan uzak ve tarafsız işleyen mekanizmalara sahip değildir. Ayrıca algoritmalar mevcut sistemi değiştirmeye değil de, pekiştirmeye neden olmaları nedeniyle de etik sorunlara neden olabilmektedir. Çünkü algoritmalar ile mevcut sistemdeki etik sorunlar aşılmamakta, tam tersine korunmaktadır. Jagadish'e göre (2016), algoritmaların dünyanın mevcut durumunu öğrenme, kodlama ve dolayısıyla değişmeyi zorlaştırma eğilimi vardır. Bu durum statükoyu korumakta; filtre balonlarını ve yankı odalarını ${ }^{1}$ sürdürmeye, dolayısıyla da farklı görüşlere tanık olmayı engellemeye neden olmaktadır. Binark (2017: 19), bu durumu "algoritmaların yaratthğı yankı odalarında siyasal katılımın olanaksızlığı” olarak tanımlamaktadır. Farklı fikirlere erişimi zorlaştırmaları açısından algoritmalar, ideal bir demokrasi anlayışına ulaşmanın önünde bir engel oluşturmaktadır. Ayrıca algoritmalar, mevcut kalıpları koruyarak tüketim odaklı yapıyı da devam ettirmeye hizmet etmektedir.

\footnotetext{
${ }^{1}$ Yankı odası etkisine göre, internet siteleri kullanıcılara yönelik içerikleri kişiselleştirerek, kullanıcıları karşıt görüşlerden uzak kalacakları yankı odaları içerisine yerleştirmektedir. Filtre balonu kavramı ise internet ortamında kullanıcıların yaratıcılıklarını ve bakış açılarını daraltacak şekilde kişiselleştirilmiş içeriklere maruz kaldıkları, başka bir deyişle farklı bakış açılarından izole olacak şekilde filtre balonu içerisinde olduklarını açıklamaktadır (Narin, 2018: 240-241).
} 
Enformasyonun asimetrik dağılımı da algoritmaların bir diğer sonucu olarak karşımıza çıkmaktadır. Algoritmalar nedeniyle kullanıcılar, verilere kurumların perspektifinden bakmaktadırlar. Bu bağlamda, bir büyük veri uçurumu ortaya çıkmaktadır. "Büyük veri uçurumu" ifadesi, veri erişimindeki asimetrilerden kaynaklanan gerilimleri vurgulamaktadır. Bu uçurum, yalnızca kullanıcıların aracılık eksikliğini değil, aynı zamanda çok az internet ve teknoloji şirketinin pazara hâkim olduğunu da vurgulamaktadır (Richterich, 2018: 40-41).

Algoritmalar geliştikçe ve dönüştükçe beraberinde getirdikleri etik sorunların azalıp azalmayacağı ise tartışmalı bir konudur. Ancak algoritmaların etkili bir şekilde işleyebilmesi için bazı temel etik kurallara ihtiyaç olduğu açıktır. Önümüzdeki yıllarda algoritmaların yükselişiyle birlikte, makine öğrenimi ${ }^{2}$ algoritmalarını kullanmak için uygun etik kurallar geliştirilmesi daha da önemli hâle gelecektir (Jameel vd., 2020). Algoritmaların etik ihlallerini tartışan ve bu konunun çözümüne odaklanan çalışmaların artması ise algoritma ihlallerinin azalabilmesi açısından umut vadetmektedir.

Cave ve diğerlerine göre (2018: 562-574), algoritmaların etik ihlallerinin önlenebilmesi için etik ilkelerle uyumlu ve etik akıl yürütme kapasitesine sahip (ahlaki sorumluluklara veya haklara sahip) algoritmalar yaratılmalıdır. Örneğin ATM'ler ve fiyat karşılaştırma algoritmaları, kullanıcıları dolandırmayacak şekilde tasarlanmalı, böylece etik olarak kabul edilebilir bir güvenlik seviyesine sahip olmalıdırlar. Ayrıca bir sağlık algoritması, hastalara ilaçlarını almaları gerektiğini hatırlatmanın aşırı bir davranış mı yoksa sadece gerekli bakımının bir parçası mı olacağı sonucunu çıkarabilirse etik açıdan daha uygun olacaktır. Binark ise (2017: 23), algoritmalara dayalı sorunların aşılmasında kullanıcının failliğinin önemini vurgulamaktadır: "bireylere düşen ilk iş, benzerseverliği besleyen yankı odalarının dışına çıkacak, algoritmaları yanıltacak direniş stratejileri/oyunlarını büyük bir ciddiyetle geliştirmek/tasarlamak olmalıdır. Böylece sosyal medya akışımızda çeşitli ve farklı söylemsel pratiklerle karşılaşmak olanaklı olur. Hak odaklı bir bakış açısını gerek kullanım pratiklerinde merkeze almak gerekse platform kapitalizminde bunun temini için mücadele yolları geliştirmek için daha fazla kafa yormamı gerekmektedir".

Yukarıda sıralanan tartışmalardan yola çıkarak algoritmalara dayalı etik ihlallerin çözümünde hem karar vericilerin ve geliştiricilerin hem de kullanıcıların etik ihlalleri engellemeye yönelik çabalarının önemli olabileceği söylenebilecektir.

\footnotetext{
${ }^{2}$ Makine öğrenimi kavramı, algoritmaların öğrenebilirliğini ve bu doğrultuda hareket edebilirliğini ifade etmektedir.
} 
Bu çabalara ek olarak derin öğrenme ile algoritmaların kendilerinin de alacağı doğru kararlar aracılığıyla etik ihlaller azaltılabilecektir. Ancak hem karar vericilerin ve kullanıcıların ne yönde çabaları olacağı hem de derin öğrenmeye bağlı algoritmaların doğru kararları alabileceklerine yönelik görüşün geçerli olup olmayacağı belirsizdir. Bu açıdan, algoritmaların etik ihlallerinin gelecekte azalıp azalmayacağı tartışmaları varlığını sürdürecek gibi gözükmektedir.

\section{Dijital Gazetecilikte Algoritmalar ve Etik}

Algoritmalar, modern bilgi ekonomisinin her alanında olduğu gibi gazetecilik alanında da giderek daha fazla kullanılmaktadır. Bu teknolojiler çı̆̆ gibi büyüyen enformasyon akışını verimli bir şekilde ehlileştirdiği ve kişiselleştirilmiş içerik akışını mümkün kıldığı için sıklıkla övgüyle karşılanmaktadır (Steiner, 2012). Ancak enformasyonu sıralamak, oluşturmak ve görünür kılmak için algoritmaların gazetecilikte artan kullanımı, bu teknolojinin temel çalışma prensipleri ve enformasyon dağıtımı üzerindeki etkisi hakkında kritik yeni etik soruları da ortaya çıkarmaktadır (Gillespie, 2014). Araştırmacılar, algoritmik yanlılığa ilişkin farkındalığı artırmak ve algoritmik etkiyi görmezden gelen ya da gizleyen bulanıklığa karşı koymak için algoritmik hesap verebilirlik çağrısında bulunmaktadır (Diakopoulos, 2015; Pasquale, 2015). Başka bir anlatımla algoritmaların yaşamın her alanına hızla nüfuz etmesi, diğer çok sayıda alanda olduğu gibi gazetecilik alanında da endişelere neden olmaktadır. Haberlerin oluşturulma ve dağıtılıp gösterilme yollarının algoritmalar tarafindan belirlenmesi, dijital gazetecilik süreçlerinde haberin üretiminden tüketimine kadar geçen süreçte etkili yeni bir teknoloji olmakla birlikte, sosyoteknik koşullar bağlamında yasal ve etik birçok tartışmayı da beraberinde getirmektedir.

Çalışma ortamlarının otomasyonu, sadece gazeteciliği değil, tüm sektörleri etkileyen bir gerçektir. Ancak habercilik süreçlerinin otomatikleştirilmesi, bireylerin makinelerle ikame edilmesinin ötesine geçerek içeriklerin doğruluğu ve yayınlanan bilgiler üzerinde yeni kontrol alanlarının oluşturulması gibi yeni bir deontolojik tartışmaya da yol açmaktadır. Dolayısıyla haberler için nesnellik ve tarafsızlık talepleri, artk haber metninin ötesine geçmiştir. Haberi oluşturmak için kullanılan veri depolama araçları, veri işleme aşamaları ve bu verileri yorumlayarak onları bir habere dönüştürmekten sorumlu olan algoritmanın oluşturulmasına yönelik etik tartışmalar (Túñez-Lopez vd., 2019: 1415) çağdaş gazetecilik araştırmalarında ön plana çıkan konular arasındadır. Dijital gazetecilikte algoritmalardan kaynaklanan etik sorunların tespitinin ve sınırlarının çizilmesinin güçlüğünün nedeni, konunun toplum bilimleri perspektifinden medya etiğinin bir alt kolu 
olan gazetecilik etiğiyle bilgisayar bilimleri perspektifinden siberetik tartışmalarının kesişiminde yer almasıdır. Enformasyon etiği, internet etiği, robot etiği, makine etiği ve bilgisayar etiği de alanın sınırları içinde yer alan belli başlı alt başlıklar olarak karşımıza çıkmaktadır (Dörrr ve Hollnbuchner 2016).

Algoritmaların gazetecilik alanında neden olduğu etik sorunlar çeşitli düzeylerde karşımıza çıkmaktadır. Veri arama ve verinin kaynağı (Bradshaw, 2014), algoritmik otorite (Carlson, 2014), algoritmik nesnellik (Gillespie, 2014), algoritmik şeffaflık (McBride ve Rosenstiel, 2014), verilerin kötüye kullanımı (Zion ve Craig, 2014), koda gömülü değerler ve akıl yürütme (Kraemer, van Overveld ve Peterson, 2011; Young ve Hermida, 2014) ile algoritmik hesapverebilirlik (Diakopoulos, 2015) alanda tartışılan konuların başlıcalarıdır. Tüm bunlara ek olarak geleneksel gazeteciliğin tartışılagelen "nesnel habercilik, rüşvet alma, gerçek ve kurgunun ayrılması, PR veya reklamcılık ayrımı, bildirilen olayların doğruluğu, mahremiyet, telif hakkına saygı veya uygun araştırma yöntemlerinin kullanılması" gibi etik sorunlar da profesyonel gazetecilikte algoritmaların kullanımı bağlamında yeniden tartışmaya açılan konulardır" (Dörrr ve Hollnbuchner 2016: 5).

Gelecekte "Tıpkı sosyal medya platformları gibi, toplayıcı uygulamaların da (aggregator apps) ${ }^{3}$ daha geniş (etik) sorumluluklarla karşı karşıya kalmaya başlaması gerekecek ve bu giderek artan bir şekilde bu tür platformların da editoryal gözetim altına almak anlamına gelecektir" (Newman vd., 2019: 33). Kısacası; değerleme, hiyerarşi ve içerik oluşturma ile ilgili tüm kararları doğrudan algoritmanın inisiyatifine bırakmadan haber yapma sürecinde algoritmanın kullanımının nasıl gerçekleştirilebileceği tartışma konusudur (Túñez-Lopez vd., 2019: 1416).

Gazetecilikte kullanılan algoritmalara ilişkin en temel etik kural, veri güvenliğinin ve geçerliliğinin sağlanmasıdır. Örneğin finans haberlerinde yanlış verilere dayaIı olarak yanlış hisse fiyatları bildirildiğinde etik sorunlar görülmektedir. Benzer şekilde eksik veriler de yanlılığa neden olabilmekedir. Kullanılan verilerin haber konusuna uygunluğu, verinin nereden geldiği, veriyi kimin ve nasıl topladığı konularında da etik sorunlarla karşılaşılabilmektedir. Veriler toplanırken kişisel verilerin korunması konusunda da hassas davranılmalıdır. Medya kuruluşunun veriyi işleme ve ticari olarak kullanma hakkına sahip olması da gerekmektedir (Dörrr ve Hollnbuchner 2016: 9).

\footnotetext{
${ }^{2}$ Çeşitli çevrim içi kaynaklardan topladığı içerikleri bir araya getiren ve kullanıcının rahatlığı için tek bir platformda görüntüleyen web ya da mobil uygulamalar. Toplayıcı uygulamalar ilgili içerik ögelerini toplar ve bu içerikleri ya kendi platformunda gösterir ya da bu içeriklere linkler verir. Apple News, Google News, Flipboard ve News360 popüler haber derleyici uygulamalardandır. Türkçe içerik derleyen Bundle ve Nabız da bu platformlara örnek gösterilebilir.
} 
Algoritmaların neden olduğu bir diğer etik sorun kişiselleştirilmiş haber akış teknolojilerinde gözlenmektedir. Haber gösterimlerini okur tercihlerine göre özelleştirmek için farklı algoritmaların kullanıldığı haber endüstrisi, bir yandan okurları enformasyon yükünden kurtarırken öte yandan politik kutuplaşma başta olmak üzere yeni etik sorunlara neden olmaktadır. İnsanlar, kişiselleştirilmiş haber tavsiye teknolojileri için hangi kişisel verilerinin kullanıldığı ve bu tür bir algoritmik iyileştirmenin nasıl ortaya çıktığı konusunda çok az bilgiye sahiptir (Harrabam vd., 2018). Görüldüğü üzere algoritmaların gazetecilikte kullanılmasından kaynaklanan etik sorunlar, haber üretiminden tüketimine kadar çeşitli aşamalarda ortaya çıkabilmektedir. Son dönemde, hakikat ötesi çağ tartışmalarına da paralel olacak şekilde en çok üzerinde durulan etik konu ise algoritmik hesapverilebilirlik ve şeffaflık olarak karşımıza çıkmaktadır.

\subsection{Algoritmik Hesapverilebilirlik ve Şeffaflık}

Algoritmik kürasyondan otomatik yazma ve haber botlarına kadar haber üretiminde algoritmik sistemlerin yaygın kullanımı, gazetecilik etiğinin temel bir ilkesi olarak şeffaflığın yeniden sorgulanmasına neden olmaktadır (Diakopoulas ve Koliska, 2017: 809). Algoritmalar, belirli maddi özelliklere sahip teknik nesneler olarak görülse de aynı zamanda çoklu anlamlar taşıyan sosyal yapılardır. Algoritmik hesap verilebilirlik tartışmalı ama gerçekleştirilmesi zor bir süreçtir. Algoritmik mekanizmalar ve sistemler karmaşıktır ve şeffaflıkları çoğunlukla belirsizdir. Tam da bu nedenle şu anda, gazetecilikte algoritmaların kullanımına ilişkin geniş çapta kabul gören bir etik kural bulunmamaktadır (Zamith, 2019: 1; Diakopoulas ve Koliska, 2017: 809). Algoritmik şeffaflığı kolaylaşttran yönergelere ihtiyaç duyulduğu ise güncel araştırmalarda vurgulanmaktadır (Diakopoulas ve Koliska, 2017: 809). Şeffaflık, algoritmaların etik ve hesap verebilirliğine yönelik yaklaşımlardan yalnızca biridir (Dörrr ve Hollnbuchner 2016) ve sektörde norm ve uygulama olarak ilgi görmektedir (Diakopoulas ve Koliska, 2017: 811). Deuze şeffaflı̆̆ı "gazeteciliğin hem içindeki hem de dışındaki insanlara izleme, kontrol etme, eleştirme ve hatta gazetecilik sürecine müdahale etme şansı verme yolları" olarak tanımlamaktadır (2005, 455). Şeffaflık, izleyicilerin haber üretim sürecinden ve haberlerin arkasındaki gazetecilerin çalışma pratiklerinden daha fazla haberdar olmaları bağlamında kıymetlidir (Diakopoulas ve Koliska, 2017: 810). Bu gerekçelerle bazı popüler basın kuruluşlarının habercilikte kullandıkları algoritmalara ilişkin bazı bilgileri okurlarıyla paylaştıkları görülmektedir. Örneğin ProPublica, bazı araştırmalarıyla birlikte istatistiksel metodolojileri de açıklayan beyaz sayfalar yayımlamıştır (Grochowski Jones ve Ornstein, 2016). BuzzFeed, FiveThirtyEight ve diğer haber kuruluşları, tamamını olmasa da bazı veriye dayalı makalelerde kullandık- 
ları kodları Github'da paylaşarak verilerini açmaktadır. The New York Times, tavsiye motoru gibi bazı haber teknolojilerinin nasıl çalışth̆̆na dair teknik makalelere yer veren Open adlı bir blog yayımlamaktadır (https://open.nytimes.com/). BBC gibi diğer haber kuruluşları, kullandıkları algoritmik araçlardan bazılarının ayrıntularını açıklamak için akademik makaleler yayımlamaktadır (Shearer, Simon ve Geiger 2014). Öte yandan algoritma şeffaflığını sağlamak kadar bu verileri anlamlandırabilecek okur kitlesi oluşturmak da elzemdir. Bu nedenle etik kurallar kadar dijital medyaokuryazarlığı becerilerinin geliştirilmesine ilişkin çabalar da gazetecilik etiğinden bağımsız değildir.

Okurlar bir analiz gerçekleştirmek, bir model belirlemek veya bir bulguyu haberleştirmek için yapay zekâ araçlarının gazetecilikte nasıl kullanıldığına dair şeffaf bilgileri öğrenme hakkına sahip olmalıdır. Ancak algoritma şeffaflığına dair bu açıklamaların teknik olmayan terimlere çevrilmesi ve okurların yapay zekânın nasıl kullanıldığını ve seçimlerin nasıl yapıldığını anlamasını sağlayacak şekilde kısa ve öz bir şekilde anlatılması gerekmektedir (Hansen vd., 2017). Yapay zekâ, “Google, Facebook ve Twitter'da görüldüğü gibi” zaten güçlü olanların ellerinde daha fazla güç toplama eğiliminde olduğundan, bilgisayar tarafindan oluşturulan haberlerin etik, ahlaki ve işleyişle ilgili hususlarının kapsamlı bir şekilde gözden geçirilmesini gerekli kılmaktadır (Linden, 2017: 73).

Algoritmik hesapverilebilirlik ve şeffaflık, gazetecilik etiğinde temel tartışma konularından biri olsa da bazı araştırmacılar, algoritmik şeffaflığın mümkün olamayacağını ya da etik değerlendirme için eksik kalacağını iddia etmektedirler (Zamith, 2019: 13). Çünkü kodların çalışma mantığının paylaşılması tehlikeli bir "şeffaflık yanılsaması" ortaya çıkarmakta ve sistemlerin içine bakma becerisini onları yönetme gücüyle eşitlemektedir (Heald, 2006). Dahası, bir sistemin teknik karmaşıklığı onu yaratıcıları için bile anlaşılmaz hâle getirebilmektedir (Burrell, 2016). Örneğin algoritmalar sürekli olarak yeni girdilerden öğrenmeyi sürdürmektedir. Bu nedenle bir algoritmanın kaynak kodunu açma ve veri kümelerini test etme çabaları zamansal olarak bağımlıdır. Sonuç olarak bu çaba, bir algoritmanın işlevselliğinin yalnızca bir anlık görüntüsünü verebilmektedir (Ananny ve Crawford, 2018). Görüldüğü üzere algoritmalar ve gazetecilik etiği çok katmanlı olup; teknolojik, toplumsal, ekonomik bağlamlarda ele alınması gereken bir konu olarak karşımıza çıkmaktadır. Bu kapsamda, bu çalışmanın ilerleyen bölümünde uluslararası akademik gazetecilik dergilerinde konunun ele alınış biçimi saptanarak tartışmaya açılmıştır. 


\section{Araştırmanın Tasarımı}

Araştırmada gazetecilik disiplini bağlamında algoritma etiği ile ilgili yayımlanmış çalışmalar incelenmiştir. Bu kapsamda, mevcut durumu kapsamlı bir şekilde ortaya koyabilmek adına yöntem olarak içerik analizi tercih edilmiştir. Örneklem olarak ise gazetecilik alanınde önde gelen üç dergi tespit edilerek son yıllarda yayımladıkları makaleler ele alınmıştır. Bu kapsamda araştırma soruları belirlenmiştir:

AS1: Algoritmalarla ilgili çalışmaların dijital gazetecilik etiğiyle ilişkileri nelerdir?

AS2: Algoritmalar hakkında etik sorunları inceleyen gazetecilik alanında yayımlanmış çalışmalardaki güncel, metodolojik ve kuramsal eğilimler nelerdir?

AS3: Algoritmalar ile ilgili gazetecilik alanında yayımlanmış çalışmalar hangi etik sorunları vurgulamaktadır?

Bu sorulardan yola çıkılarak içerik analizi ile elde edilen verilere yönelik bir değerlendirme gerçekleştirilmiştir. Algoritmalar ile ilgili gazetecilik alanında yayımlanmış çalışmaların ortaya koydukları etik sorunlar tespit edilerek alanda algoritma etiği konusunun hangi yönlerinin vurgulandığı ya da ihmal edildiği de sorgulanmıştır.

\subsection{Yöntem}

Araştırmada örneklem olarak seçilen makaleler araştırmacılar tarafindan oluşturulan kategorilere göre hazırlanan kodlama cetveline işlenerek nitel içerik analizine tabi tutulmuştur. İçerik analizi, veriden onun içeriğine ilişkin tekrarlanabilir ve geçerli sonuçlar çıkarmak üzere kullanılmaktadır (Krippendorff, 1980). İçerik analizi, metin içeriklerini kategorize ederek bu kategoriler arasındaki ilişkiselliği ortaya koyması (Riffe, Lacy ve Fico, 2005: 3) nedeniyle çalışmanın amacına hizmet etmektedir. Nitel içerik analizi, verinin altında yatan örtük anlamları saptamak için kategoriler geliştirmektedir (Schreier, 2012). Bu nedenle çalışmada nitel içerik analizi kullanılmıştır ve elde edilen bulgular, kavramsal kategoriler ve temalar üzerinden betimsel olarak yorumlanmıştır. Araştırma güvenilirliğini sağlamak adına makaleler ikinci bir kodlayıcı tarafindan yeniden kodlanmıştır.

Çalışmada algoritmalar ve gazetecilik etiği ile ilgili güncel araştırmaların tematik analizinin yapılması yoluyla konunun mevcut dijital gazetecilik çalışmalarındaki güncel, metodolojik ve teorik eğilimlerinin belirlenmesi hedeflenmiştir. Böylece algoritmalarla ilgili araştırma gündeminin örüntüleri, dijital gazetecilik etiğiyle ilişkili olarak tartışmaya açılmıştır. Algoritmaların gazetecilikteki etik sorunlarının genel bir tespitini yapmak adına, alanda önde gelen üç dergide yer alan çalışmalar ele alınmıştır. Bu sayılardaki algoritmalar ile ilgili çalışmanın odağı, kuramı, 
yöntemi, örneklemi ve bulguları ele alınmıştır. Algoritmalar ve algoritma etiğinin çağdaş dijital gazetecilik çalışmalarında görece yeni bir çalışma alanı olarak karşımıza çıkması, araştırmanın çağdaş dönemlerle sınırlı tutulmasını gerekli kılmıştır.

\section{2. Örneklem ve Sınırlılıklar}

Araştırmanın örneklemini Scimago Journal ve Country Rank'in Journal Rankings on Communication 2019 yılı listesine göre (https://www.scimagojr.com/journalrank.php?category=3315\&year=2019) en üst sırada yer alan üç gazetecilik temalı akademik yayın olan Digital Journalism, Journalism Studies ve Journalism\&Mass Communication Quarterly oluşturmaktadır. Scopus veritabanında yer alan bilgilerden geliştirilen dergileri ve ülke bilimsel göstergelerini içeren SCImago'nun (SJR) dergi sıralaması, H indexi, toplam yayın sayısı, referanslar, yayınların aldığı atıf sayısı gibi faktörler dikkate alınarak oluşturulmaktadır. Araştırmada Digital Journalism, Journalism Studies ve Journalism ve Mass Communication Quarterly dergilerinin 2019 ve 2020 yılındaki tüm sayıları incelenmiştir.

Journalism ve Mass Communication Quarterly (JMCQ), üç ayda bir yayımlanan hakemli bir dergidir. Gazetecilik ve kitle iletişim araştırmalarına odaklanan dergi, kitle iletişimi ile ilgili en eski hakemli bilimsel dergidir. 1924 yılında kurulan bu dergide; gazetecilik ve kitle iletişimindeki kuramsal ve metodolojik gelişmeler, uluslararası iletişim, medya teknolojileri ve toplum, reklamcılık, halkla ilişkiler, gazetecilik tarihi, medya hukuku ve politikası, medya yönetimi ve ekonomisi, iletişim ve siyaset, sağlık iletişimi ve bu konularla sınırlı olmamak üzere iletişim ile ilgili orijinal makaleler ve kitap incelemeleri yayımlanmaktadır (Journalism ve Mass Communication Quarterly).

Çalışma kapsamında incelenen diğer bir dergi olan Journalism Studies 2000 yılından bu yana yayımlanmaktadır. Journalism Studies hem akademik hem de mesleki uygulama alanı olarak gazeteciliğin incelenmesi ve eleştirel tartışılması için uygun bir mecra sağlamaktadır. Dergi; kapsayıcı bir bakış açısına sahiptir ve çeşitli jeopolitik arka planlardan gelen başvuruları teşvik etmektedir. Dergi; gazetecilik kuramları, gazetecilik çalışmalarında epistemolojik kaygılar, gazetecilik araştırmalarında metodolojik uygulamalar, gazeteciliğin siyasi boyutları, gazetecilikte etik ve yasal kaygılar ve uygulamalar, gazeteciliğin sosyal ve kültürel boyutları, teknoloji ve gazetecilik, gazeteciliğin ekonomik yönleri, gazetecilik ve izleyicileri, gazeteciliğe ilişkin tarihsel araşttrmalar, gazetecilikte çeşitlilik sorunları ve gazetecilik eğitimi gibi konuları kapsamaktadır (Journalism Studies).

2013 yılından beri yayımlanan Digital Journalism ise yılda 10 sayı yayımlamaktadır. Derginin kapsamı, dijital gazetecilik ve dijital gazetecilik çalışmalarına (DJS) 
yönelik uluslararası araştırmalardır. Dergi, teknoloji ile ilgili gazetecilik araştırmalarının lideri konumunu korumayı ve çok sayıda disiplinle kesişen konuları ilerletmek için kritik bir forum sağlamayı amaçlamaktadır (Digital Journalism).

Seçilen dergilerdeki "review" yazıları bu çalışmaya dâhil edilmemiş, yalnızca teorik ve araştirma makalesi olduğu değerlendirilen makaleler incelenmiştir. Bahse konu dergilerde, ilgili dönemde yayınlanan çalışmalardan başlığında, özetinde veya anahtar kelimelerinde "algoritma" kelimesi geçen makaleler örneklem olarak kabul edilmiştir. Araştırma tasarlanırken, önce yalnızca "algoritma" ifadesini anahtar sözcük olarak kullanan makalelerin incelenmesi planlanmış ancak örneklemin yetersiz kalacağı görüldüğünden başlık veya özette de söz konusu ifadenin varlığı aranarak incelenen çalışma sayısı arttırılmıştır. Çalışmada incelenen üç dergi dışında "algoritma" konulu makaleleri yayımlayan dergilerin zaman kısıtı nedeniyle çalışmaya dâhil edilememesi, bu çalışmanın sınırlılığını oluşturmaktadır.

Tablo-1. Araştırma Kapsamında İncelenen Toplam Makale Sayısı

\begin{tabular}{|c|c|c|c|}
\hline & $\begin{array}{c}\text { Toplam } \\
\text { Sayı }\end{array}$ & $\begin{array}{c}\text { incelenen Toplam } \\
\text { Makale Sayısı }\end{array}$ & $\begin{array}{c}\text { Başlık/Özet/Anahtar Kelimelerde Algoritma } \\
\text { Sözcüğü Geçen Makale Sayısı }\end{array}$ \\
\hline $\begin{array}{l}\text { 3 Derginin } 2019 \\
\text { ve 2020 sayıları }\end{array}$ & 60 & 497 & 31 \\
\hline
\end{tabular}

Üç dergide 2019 ve 2020 yıllarında yayınlanan ve başlığında, özetinde veya anahtar kelimelerinde "algoritma" kelimesi geçen çalışmaların sayısı Tablo-1'de gösterilmektedir. Buna göre 60 sayıda yayınlanan 497 makale incelenerek gerekli kriterleri sağlayan toplam 31 makale (incelenen çalışmaların \%6'sı) araştırmaya dâhil edilmiştir. Söz konusu örneklemin dergilere göre dağılımı Tablo-2'de gösterilmiştir.

Tablo-2. Araştırma Kapsamında İncelenen Makalelerin Dergilere Göre Dağılımı

\begin{tabular}{|c|c|c|c|}
\hline & Sayı & $\begin{array}{c}\text { Her Sayıda Yer Alan } \\
\text { Makale Sayısı }\end{array}$ & $\begin{array}{c}\text { Başlık/Özet/Anahtar Kelimelerde } \\
\text { Algoritma Sözcügüü Geçen Makale } \\
\text { Sayısı }\end{array}$ \\
\hline 2019 (Vol 7) & 1 & 8 & - \\
\hline $2019($ Vol 7) & 2 & 7 & 1 \\
\hline $2019($ Vol 7) & 3 & 7 & 1 \\
\hline $2019($ Vol 7) & 4 & 7 & 3 \\
\hline $2019($ Vol 7) & 5 & 7 & 1 \\
\hline $2019($ Vol 7) & 6 & 7 & 1 \\
\hline $2019($ Vol 7) & 7 & 7 & - \\
\hline
\end{tabular}




\begin{tabular}{|c|c|c|c|}
\hline $\begin{array}{l}2019 \text { (Vol 7) } \\
\text { (Özel Sayı) }\end{array}$ & 8 & 10 & 10 \\
\hline 2019 (Vol 7) & 9 & 7 & - \\
\hline 2019 (Vol 7) & 10 & 2 & - \\
\hline & & Toplam: 69 & Toplam: 17 \\
\hline 2020 ( Vol 8) & 1 & 10 & 1 \\
\hline 2020 (Vol 8) & 2 & 8 & - \\
\hline 2020 (Vol 8) & 3 & 7 & - \\
\hline 2020 ( Vol 8) & 4 & 6 & 1 \\
\hline 2020 (Vol 8) & 5 & 6 & 2 \\
\hline 2020 ( Vol 8) & 6 & 7 & 1 \\
\hline 2020 ( $\mathrm{Vol} 8)$ & 7 & 5 & 1 \\
\hline 2020 (Vol 8) & 8 & 6 & - \\
\hline 2020 (Vol 8) & 9 & 6 & 2 \\
\hline \multirow[t]{2}{*}{2020 ( Vol 8) } & 10 & 5 & - \\
\hline & & Toplam: 66 & Toplam: 8 \\
\hline $\begin{array}{l}\text { DERGI GENEL } \\
\text { TOPLAM }\end{array}$ & 20 & 135 & 25 (Incelenen çalışmaların \%81'i) \\
\hline
\end{tabular}

\begin{tabular}{|c|c|c|c|}
\hline \multicolumn{5}{|c|}{ JOURNALISM STUDIES } \\
\hline Yıl & Sayı & $\begin{array}{c}\text { Her Sayıda Yer Alan } \\
\text { Makale Sayıs }\end{array}$ & $\begin{array}{c}\text { Başlık/Özet/Anahtar Kelimelerde Algo- } \\
\text { ritma Sözcüğü Geçen Makale Sayısı }\end{array}$ \\
\hline $2019($ Vol 20) & 1 & 8 & - \\
\hline $2019($ Vol 20) & 2 & 8 & - \\
\hline $2019($ Vol 20) & 3 & 8 & - \\
\hline $2019($ Vol 20) & 4 & 7 & - \\
\hline $2019($ Vol 20) & 5 & 8 & - \\
\hline $2019($ Vol 20) & 6 & 8 & - \\
\hline $2019($ Vol 20) & 7 & 8 & - \\
\hline $2019($ Vol 20) & 8 & 8 & 1 \\
\hline $2019($ Vol 20) & 9 & 8 & - \\
\hline $2019($ Vol 20) & 10 & 7 & - \\
\hline $2019($ Vol 20) & 11 & 9 & - \\
\hline $2019($ Vol 20) & 12 & 9 & - \\
\hline $2019($ Vol 20) & 13 & 9 & - \\
\hline $2019($ Vol 20) & 14 & 8 & \\
\hline $2019($ Vol 20) & 15 & 9 & - \\
\hline
\end{tabular}




\begin{tabular}{|c|c|c|c|}
\hline 2019 (Vol 20) & 16 & 12 & - \\
\hline & & Toplam: 134 & Toplam: 2 \\
\hline 2020 (Vol 21) & 1 & 8 & - \\
\hline 2020 (Vol 21) & 2 & 8 & - \\
\hline 2020 (Vol 21) & 3 & 8 & - \\
\hline 2020 (Vol 21) & 4 & 8 & - \\
\hline 2020 (Vol 21) & 5 & 8 & - \\
\hline 2020 (Vol 21) & 6 & 8 & - \\
\hline 2020 (Vol 21) & 7 & 9 & 2 \\
\hline 2020 (Vol 21) & 8 & 9 & - \\
\hline 2020 (Vol 21) & 9 & 7 & - \\
\hline 2020 (Vol 21) & 10 & 8 & - \\
\hline 2020 (Vol 21) & 11 & 8 & - \\
\hline 2020 (Vol 21) & 12 & 8 & - \\
\hline 2020 (Vol 21) & 13 & 8 & - \\
\hline 2020 (Vol 21) & 14 & 7 & - \\
\hline 2020 (Vol 21) & 15 & 8 & - \\
\hline \multirow[t]{2}{*}{2020 (Vol 21) } & 16 & 8 & - \\
\hline & & Toplam: 128 & Toplam: 2 \\
\hline $\begin{array}{l}\text { DERGI GENEL } \\
\text { TOPLAM }\end{array}$ & 32 & 262 & 4 (İncelenen çalışmaların \%13’ü) \\
\hline
\end{tabular}

\begin{tabular}{|c|c|c|c|}
\hline \multicolumn{5}{|c|}{ JOURNALISM ve MASS COMMUNICATION QUARTERLY } \\
\hline YıI & Sayı & $\begin{array}{c}\text { Her Sayıda Yer Alan } \\
\text { Makale Sayısı }\end{array}$ & $\begin{array}{c}\text { Başlı/Özet/Anahtar Kelimelerde Algorit- } \\
\text { ma Sözcüğ̈ Geçen Makale Sayısı }\end{array}$ \\
\hline 2019 (Vol 96) & 1 & 15 & 2 \\
\hline 2019 (Vol 96) & 2 & 13 & - \\
\hline 2019 (Vol 96) & 3 & 11 & - \\
\hline 2019 (Vol 96) & 4 & 9 & - \\
\hline & & Toplam: 48 & Toplam: 2 \\
\hline 2020 (Vol 97) & 1 & 13 & - \\
\hline 2020 (Vol 97) & 2 & 10 & - \\
\hline 2020 (Vol 97) & 3 & 17 & Toplam: 0 \\
\hline 2020 (Vol 97) & 4 & 12 & (Incelenen çalışmaların \%6'sı) \\
\hline & & Toplam: 52 & \\
\hline $\begin{array}{c}\text { DERGi GENEL } \\
\text { TOPLAM }\end{array}$ & 8 & 100 & \\
\hline
\end{tabular}


Tablo-2'de görüldüğü üzere araşttrmaya dâhil edilen 31 makalenin \%81'i (25 makale) Digital Journalism'de yayınlanmıştır. Journalism Studies'ten 4 (\%13), Journalism ve Mass Communication Quarterly'den ise 2 (\%6) makale çalışma kapsamında değerlendirilmiştir. Dijital Journalism'in çevrim içi gazeteciliğe odaklı bir dergi olması nedeniyle algoritmalar ile ilgili çalışmalara incelenen diğer dergilere kıyasla daha çok yer verdiği düşünülmektedir. Journalism Studies ve Journalism ve Mass Communication Quarterly, yalnızca dijitalleşmeye odaklanmayan, daha geniş bir çerçevede gazetecilik alanına odaklanan dergilerdir. Ayrıca algoritmaların gazetecilikteki kullanımının yaygınlık kazanması nedeniyle konuya ilginin son yıllarda dijital gazetecilik araştırmalarında da arttğı ancak konunun yeterince incelenmediği söylenebilecektir.

\section{Araştırmanın Bulguları:}

Örneklem olarak seçilen dergilerde, ilgili dönemde yayınlanan algoritmalarla ilgili 31 çalışmaya ilişkin bulgular bu başlık altında incelenmiştir. Bahse konu çalışmalar Tablo 3'te de görülebileceği gibi odaklarına, araştırmada kullanılan kuram/ kavramlara, çalışmanın yöntemine, örneklemine, örneklemin seçildiği ülke ya da ülkelere ve algoritma etiğine yönelik bulgulara göre ayrı kategoriler altında değerlendirilmiştir. Değerlendirme sonucunda algoritmalar ile ilgili makalelerin odağının kullanıcılar, üretim aşaması ve çalışma pratikleri ya da metin analizleri olduğu görülmüştür. Çalışmaların büyük bir bölümünün ise algoritmaların üretim aşaması ve çalışma pratikleri (\%45) ile kullanıcılar (\%29) olduğu anlaşılmıştır. İncelenen çalışmaların azının belirli ve sabit bir kuram etrafinda gerçekleştirildiği; bu kuramların ise aktör ağ kuramı, sosyal-bilişsel kuram ve Bourdieu'nun alan kuramı olduğu anlaşılmıştır. Ayrıca filtre balonları, kişiselleştirilmiş haber, makine iletişimi, sayısallaştırılmış gazetecilik, otomatize gazetecilik gibi kavramlar üzerinde durulduğu görülmüştür. Algoritmalar ile ilgili çalışmalar çoğunlukla ampirik araştırmalara dayanırken (\%62), kuramsal tartışmaya dayalı çalışmaların azınlıkta olduğu (\%38) açığa çıkmıştır. İncelenen makalalelerde sık kullanılan tekniklerin ise anket (\%19), derinlemesine görüşme (\%16) ve içerik analizi (\%13) olduğu, çalışmaların örneklermlerinin tercih edilen bu tekniklere göre farklılık gösterebildiği ve araştırmaların gerçekleştiği yer ve örneklem seçiminin çoğunlukla (\%52) ABD ve Avrupa merkezli olduğu saptanmıştır. Ayrıca incelenen çalışmaların çoğunda algoritmalara ilişkin çeşitli problemlerden bahsediliyor olsa da bu problemlerin çok azının (\%19) etik sorunlarla ilgili olduğu ortaya çıkmıştır. 
Tablo-3. Algoritmalar ve Gazeteciliği Konu Edinen Makalelerde Etik Tartş̧malara iliş̧kin Bulgular

\begin{tabular}{|c|c|c|c|c|c|c|c|c|}
\hline$\overline{\text { No }}$ & $\begin{array}{l}\text { Dergi Adı/ } \\
\text { Sayısı/Yılı }\end{array}$ & \begin{tabular}{|l|} 
Makalenin \\
Başlığı
\end{tabular} & Odağı & Kuramı & $\begin{array}{l}\text { Yönte- } \\
\text { mi }\end{array}$ & Örneklemi & Ülke/ler & Bulgular \\
\hline 1 & $\begin{array}{l}\text { Digital Jour- } \\
\text { nalism Vol } \\
7 / 2 \text { - } 2019\end{array}$ & $\begin{array}{l}\text { Interested in } \\
\text { Diversity: The } \\
\text { role of user } \\
\text { attitudes, algo- } \\
\text { rithmic feedba- } \\
\text { ck loops, and } \\
\text { policy in news } \\
\text { personalization }\end{array}$ & Kullanıcı & $\begin{array}{l}\text { Kavramlar } \\
\text { üzerinden } \\
\text { tartsşılmış: } \\
\text { filtre balon- } \\
\text { ları, kişisel- } \\
\text { leştirilmiş } \\
\text { haberler }\end{array}$ & Anket & $\begin{array}{l}1556 \text { oku- } \\
\text { yucu }\end{array}$ & Hollanda & $\begin{array}{l}\text { Problem } \\
\text { ortaya } \\
\text { koyan ve } \\
\text { çözüm } \\
\text { öneren }\end{array}$ \\
\hline 2 & $\begin{array}{l}\text { Digital Jour- } \\
\text { nalism Vol } \\
7 / 3 \text { - } 2019\end{array}$ & $\begin{array}{l}\text { Locating the } \\
\text { "Digital” in Di- } \\
\text { gital Journalism } \\
\text { Studies: Trans- } \\
\text { formations in } \\
\text { Research }\end{array}$ & $\begin{array}{l}\text { Üretim } \\
\text { aşaması/ } \\
\text { çalışma } \\
\text { pratikleri }\end{array}$ & $\begin{array}{l}\text { Kavramlar } \\
\text { üzerinden } \\
\text { tartışılmış: } \\
\text { dijital gaze- } \\
\text { tecilik }\end{array}$ & $\begin{array}{l}\text { Teorik } \\
\text { Tartş̧- } \\
\text { ma }\end{array}$ & - & - & $\begin{array}{l}\text { Problem } \\
\text { ortaya } \\
\text { koyan }\end{array}$ \\
\hline 3 & $\begin{array}{l}\text { Digital Jour- } \\
\text { nalism Vol } \\
7 / 4 \text { - } 2019\end{array}$ & $\begin{array}{l}\text { My Friends, } \\
\text { Editors, Algo- } \\
\text { rithms, and } \\
\text { I Examining } \\
\text { audience atti- } \\
\text { tudes to news } \\
\text { selection }\end{array}$ & Kullanıcı & $\begin{array}{l}\text { Kavramlar } \\
\text { üzerinden } \\
\text { tartışılmış: } \\
\text { haber tüke- } \\
\text { timi, algorit- } \\
\text { malar, eşik } \\
\text { bekçiliği }\end{array}$ & Anket & $\begin{array}{l}53.314 \\
\text { katilımcı ile } \\
\text { anket }\end{array}$ & $\begin{array}{l}\text { Toplam } \\
26 \text { ülke }\end{array}$ & $\begin{array}{l}\text { Problem } \\
\text { ortaya } \\
\text { koyan }\end{array}$ \\
\hline 4 & $\begin{array}{l}\text { Digital Jour- } \\
\text { nalism Vol } \\
7 / 4-2019\end{array}$ & $\begin{array}{l}\text { A Field Analysis } \\
\text { of Journalism } \\
\text { in the Auto- } \\
\text { mation Age: } \\
\text { Understanding } \\
\text { Journalistic } \\
\text { Transformati- } \\
\text { ons and Stru- } \\
\text { ggles Through } \\
\text { Structure and } \\
\text { Agency }\end{array}$ & $\begin{array}{l}\text { Üretim } \\
\text { aşaması/ } \\
\text { çalışma } \\
\text { pratikleri }\end{array}$ & $\begin{array}{l}\text { Bour- } \\
\text { dieu'nun } \\
\text { alan teorisi }\end{array}$ & $\begin{array}{l}\text { Derin- } \\
\text { leme- } \\
\text { sine } \\
\text { görüş- } \\
\text { me }\end{array}$ & $\begin{array}{l}12 \text { 'si yerel, } \\
1 \text { bölge- } \\
\text { sel ve } 2 \\
\text { uluslara- } \\
\text { rası haber } \\
\text { editörüyle } \\
\text { derinleme- } \\
\text { sine görüş- } \\
\text { me. }\end{array}$ & Singapur & $\begin{array}{l}\text { Problem } \\
\text { ortaya } \\
\text { koyan }\end{array}$ \\
\hline 5 & $\begin{array}{l}\text { Digital Jour- } \\
\text { nalism Vol } \\
7 / 4 \text { - } 2019\end{array}$ & $\begin{array}{l}\text { Automation, } \\
\text { Journalism, and } \\
\text { Human-Mac- } \\
\text { hine Communi- } \\
\text { cation: Rethin- } \\
\text { king Roles and } \\
\text { Relationships } \\
\text { of Humans and } \\
\text { Machines in } \\
\text { News }\end{array}$ & \begin{tabular}{|l|} 
Üretim \\
aşaması/ \\
çalışma \\
pratikleri
\end{tabular} & $\begin{array}{l}\text { Kavramlar } \\
\text { üzerinden } \\
\text { tartışılmış: } \\
\text { insan-maki- } \\
\text { ne iletişimi, } \\
\text { gazeteciliğin } \\
\text { ontolojisi ve } \\
\text { geleceği }\end{array}$ & $\begin{array}{l}\text { Teorik } \\
\text { Tartş- } \\
\text { ma }\end{array}$ & - & - & $\begin{array}{l}\text { Problem } \\
\text { ortaya } \\
\text { koyan ve } \\
\text { çözüm } \\
\text { öneren }\end{array}$ \\
\hline 6 & $\begin{array}{l}\text { Digital Jour- } \\
\text { nalism Vol } \\
7 / 5 \text { - } 2019\end{array}$ & $\begin{array}{l}\text { Machine Aut- } \\
\text { horship In Situ: } \\
\text { Effect of news } \\
\text { organization } \\
\text { and news } \\
\text { genre on news } \\
\text { credibility }\end{array}$ & Kullanıcı & $\begin{array}{l}\text { Kavramlar } \\
\text { üzerinden } \\
\text { tartşsımış: } \\
\text { otomatize } \\
\text { gazetecilik }\end{array}$ & Anket & $\begin{array}{c}355 \text { kişi ile } \\
\text { çevrim içi } \\
\text { anket }\end{array}$ & $\overline{A B D}$ & $\begin{array}{l}\text { Problem } \\
\text { ortaya } \\
\text { koyan }\end{array}$ \\
\hline
\end{tabular}




\begin{tabular}{|c|c|c|c|c|c|c|c|c|}
\hline 7 & $\begin{array}{l}\text { Digital Jour- } \\
\text { nalism Vol } \\
7 / 6 \text { - } 2019\end{array}$ & \begin{tabular}{|l} 
Beyond the \\
Bubble: Asses- \\
sing the Diver- \\
sity of Political \\
Search Results
\end{tabular} & \begin{tabular}{|l} 
Metin \\
Analizi \\
ve Kulla- \\
nıcı
\end{tabular} & \begin{tabular}{|l|} 
Kavramlar \\
üzerinden \\
tartsşılmış: \\
algoritmalar \\
aracılığıyla \\
seçmeni \\
yönlendir- \\
me/saptr- \\
ma ve filtre \\
balonları \\
\end{tabular} & \begin{tabular}{|l|} 
Içerik \\
analizi \\
\end{tabular} & \begin{tabular}{|l|}
4000 kul- \\
lanıcının \\
web arama \\
sonuçları
\end{tabular} & Almanya & \begin{tabular}{|l} 
Problem \\
ortaya \\
koyan ve \\
çözüm \\
öneren
\end{tabular} \\
\hline 8 & $\begin{array}{l}\text { Digital Jour- } \\
\text { nalism Vol } \\
7 / 8 \text { - } 2019\end{array}$ & $\begin{array}{l}\text { Atomising the } \\
\text { News: The (In) } \\
\text { Flexibility of } \\
\text { Structured } \\
\text { Journalism }\end{array}$ & $\begin{array}{l}\text { Üretim } \\
\text { aşaması// } \\
\text { çalışma } \\
\text { pratikleri }\end{array}$ & \begin{tabular}{|l|} 
Kavramlar \\
üzerinden \\
tartşıılmış: \\
yapılan- \\
dırılmış \\
gazetecilik \\
ve atomize \\
haberler \\
\end{tabular} & $\mid \begin{array}{l}\text { Içerik } \\
\text { analizi }\end{array}$ & $B B C$ & Ingiltere & \begin{tabular}{|l} 
Problem \\
ortaya \\
koyan
\end{tabular} \\
\hline 9 & $\begin{array}{l}\text { Digital Jour- } \\
\text { nalism Vol } \\
7 / 8-2019\end{array}$ & $\begin{array}{l}\text { News Algorith- } \\
\text { ms, Photojour- } \\
\text { nalism and the } \\
\text { Assumption } \\
\text { of Mechanical } \\
\text { Objectivity in } \\
\text { Journalism }\end{array}$ & $\begin{array}{l}\text { Üretim } \\
\text { aşaması/ } \\
\text { çalışma } \\
\text { pratikleri }\end{array}$ & $\begin{array}{l}\text { Kavramlar } \\
\text { üzerinden } \\
\text { tartşsılmış: } \\
\text { algoritmalar } \\
\text { ve nesnellik } \\
\text { ilişkisi, otori-- } \\
\text { te, sembolik } \\
\text { güc }\end{array}$ & $\begin{array}{l}\text { Teorik } \\
\text { Tartış- } \\
\text { ma }\end{array}$ & & & \begin{tabular}{|l|} 
Problem \\
ortaya \\
koyan
\end{tabular} \\
\hline 10 & \begin{tabular}{|l} 
Digital Jour- \\
nalism Vol \\
$7 / 8$ - 2019
\end{tabular} & $\begin{array}{l}\text { Human Still in } \\
\text { the Loop: Edi- } \\
\text { tors Reconsider } \\
\text { the Ideals of } \\
\text { Professional } \\
\text { Journalism } \\
\text { Through Auto- } \\
\text { mation }\end{array}$ & $\begin{array}{l}\text { Üretim } \\
\text { aşaması/ } \\
\text { çalışma } \\
\text { pratikleri }\end{array}$ & \begin{tabular}{|l|} 
Kavramlar \\
üzerinden \\
tartş̧ılmış: \\
otomasyon, \\
objektiflik, \\
etik
\end{tabular} & \begin{tabular}{|l|} 
Derin- \\
leme- \\
sine \\
görüş- \\
me \\
\end{tabular} & \begin{tabular}{|l|} 
Toplam \\
12 kişiden \\
oluşan \\
editöryal \\
tecrübesi \\
bulunan \\
gazeteciler
\end{tabular} & Almanya & $\begin{array}{l}\text { Problem } \\
\text { olmadığı } \\
\text { sonucuna } \\
\text { ulaşan }\end{array}$ \\
\hline 11 & $\begin{array}{l}\text { Digital Jour- } \\
\text { nalism Vol } \\
7 / 8-2019\end{array}$ & $\begin{array}{l}\text { Making Artifi- } \\
\text { cial Intelligen- } \\
\text { ce Work for } \\
\text { Investigative } \\
\text { Journalism }\end{array}$ & $\begin{array}{l}\text { Üretim } \\
\text { aşaması/ } \\
\text { çalışma } \\
\text { pratikleri }\end{array}$ & \begin{tabular}{|l} 
Kavramlar \\
üzerinden \\
tartşılmış: \\
araştrrmacı \\
gazetecilik \\
ve yapay \\
zekâ
\end{tabular} & $\begin{array}{l}\text { Teorik } \\
\text { Tartış- } \\
\text { ma }\end{array}$ & - & ABD & \begin{tabular}{|l|} 
Problem \\
ortaya \\
koyan
\end{tabular} \\
\hline 12 & $\begin{array}{l}\text { Digital Jour- } \\
\text { nalism Vol } \\
7 / 8 \text { - } 2019\end{array}$ & \begin{tabular}{|l} 
Newsbots \\
That Mediate \\
Journalist and \\
Audience Rela- \\
tionships
\end{tabular} & $\begin{array}{l}\text { Üretim } \\
\text { aşaması/ } \\
\text { çalışma } \\
\text { pratikleri } \\
\\
\text { + Kulla- } \\
\text { nıcı }\end{array}$ & \begin{tabular}{|l|} 
Kavramlar \\
üzerinden \\
tartşılmış: \\
haber botla- \\
rı ve algorit- \\
malar
\end{tabular} & \begin{tabular}{|l|} 
Karma \\
yöntem \\
(haber \\
odası \\
çalışan- \\
ları ile \\
derinle- \\
mesine \\
görüş- \\
me + \\
anket + \\
kullanı- \\
cı yo- \\
rumları \\
üzerine \\
içerik \\
analizi) \\
\end{tabular} & \begin{tabular}{|l}
3404 kişi \\
ile anket. \\
\\
120 kulla- \\
nıcı yoru- \\
mu üzerine \\
içerik \\
analizi.
\end{tabular} & $\begin{array}{l}\text { Avust- } \\
\text { ralya }\end{array}$ & $\begin{array}{l}\text { Problem } \\
\text { olmadığı } \\
\text { sonucuna } \\
\text { ulaşan }\end{array}$ \\
\hline
\end{tabular}




\begin{tabular}{|c|c|c|c|c|c|c|c|c|}
\hline 13 & $\begin{array}{l}\text { Digital Jour- } \\
\text { nalism Vol } \\
7 / 8 \text { - } 2019\end{array}$ & \begin{tabular}{|l} 
On the Democ- \\
ratic Role of \\
News Recom- \\
menders
\end{tabular} & $\begin{array}{l}\text { Üretim } \\
\text { aşaması/ } \\
\text { çalışma } \\
\text { pratikleri }\end{array}$ & $\begin{array}{l}\text { Kavramlar } \\
\text { üzerinden } \\
\text { tartşılmış: } \\
\text { algoritmalar, } \\
\text { demokrasi } \\
\text { modelleri, } \\
\text { eșik bekciliği }\end{array}$ & $\begin{array}{l}\text { Teorik } \\
\text { Tartiş- } \\
\text { ma } \\
\\
\end{array}$ & - & - & $\begin{array}{l}\text { Problem } \\
\text { ortaya } \\
\text { koyan ve } \\
\text { çözüm } \\
\text { öneren }\end{array}$ \\
\hline 14 & $\begin{array}{l}\text { Digital Jour- } \\
\text { nalism Vol } \\
7 / 8 \text { - } 2019\end{array}$ & $\begin{array}{l}\text { Public Service } \\
\text { Chatbots: Au- } \\
\text { tomating Con- } \\
\text { versation with } \\
\text { BBC News }\end{array}$ & \begin{tabular}{|l|} 
Üretim \\
aşaması// \\
çalışma \\
pratikleri
\end{tabular} & \begin{tabular}{|l|} 
Kavramlar \\
üzerinden \\
tartssıılmış: \\
chat botları, \\
haber bot- \\
ları, kamu \\
hizmeti
\end{tabular} & $\begin{array}{l}\text { İçerik } \\
\text { analizi }\end{array}$ & \begin{tabular}{|l|} 
BBC'ye ait \\
8 haber \\
botunun \\
kullanıcıyla \\
metinsel \\
etkileşimi \\
bakımın- \\
dan tekno- \\
lojik geliş- \\
mişliği test \\
edilmis. \\
\end{tabular} & |lingiltere & $\begin{array}{l}\text { Problem } \\
\text { ortaya } \\
\text { koyan ve } \\
\text { çözüm } \\
\text { öneren }\end{array}$ \\
\hline 15 & $\begin{array}{l}\text { Digital Jour- } \\
\text { nalism Vol } \\
7 / 8 \text { - } 2019\end{array}$ & \begin{tabular}{|l|} 
Selling News \\
to Audiences \\
- A Qualitative \\
Inquiry into \\
the Emerging \\
Logics of Algo- \\
rithmic News \\
Personalization \\
in European \\
Quality News \\
Media \\
\end{tabular} & $\begin{array}{l}\text { Üretim } \\
\text { aşaması/ } \\
\text { çalışma } \\
\text { pratikleri }\end{array}$ & $\begin{array}{l}\text { Kavramlar } \\
\text { üzerinden } \\
\text { tartışılmış: } \\
\text { kişiselleşti- } \\
\text { rilmiş ha- } \\
\text { berler, algo- } \\
\text { ritmalar ve } \\
\text { habercilik }\end{array}$ & $\begin{array}{l}\text { Derin- } \\
\text { leme- } \\
\text { sine } \\
\text { görüş- } \\
\text { me }\end{array}$ & \begin{tabular}{|l}
16 medya \\
çalışanıyla \\
derinle- \\
mesine \\
görüşme
\end{tabular} & \begin{tabular}{|l|} 
Hollanda, \\
Ingiltere, \\
isviçre, \\
Almanya, \\
Finlandiya
\end{tabular} & $\begin{array}{l}\text { Problem } \\
\text { ortaya } \\
\text { koyan }\end{array}$ \\
\hline 16 & $\begin{array}{l}\text { Digital Jour- } \\
\text { nalism Vol } \\
7 / 8 \text { - } 2019\end{array}$ & \begin{tabular}{|l|} 
Structured \\
Journalism and \\
the Semantic \\
Units of News
\end{tabular} & $\begin{array}{l}\text { Metin } \\
\text { analizi }\end{array}$ & \begin{tabular}{|l|} 
Kavramlar \\
üzerinden \\
tartışılmış: \\
sayısallaşt- \\
rılmış gaze- \\
tecilik, yapı- \\
landırılmış \\
gazetecilik, \\
algoritmalar \\
\end{tabular} & $\begin{array}{l}\text { Teorik } \\
\text { Tartiş- } \\
\text { ma }\end{array}$ & - & - & $\begin{array}{l}\text { Problem } \\
\text { ortaya } \\
\text { koyan }\end{array}$ \\
\hline 17 & $\begin{array}{l}\text { Digital Jour- } \\
\text { nalism Vol } \\
7 / 8 \text { - } 2019\end{array}$ & $\begin{array}{l}\text { Prioritizing the } \\
\text { Audience's } \\
\text { View of Auto- } \\
\text { mation in Jour- } \\
\text { nalism }\end{array}$ & Kullanıcı & $\begin{array}{l}\text { Kavramlar } \\
\text { üzerinden } \\
\text { tartışılmış: } \\
\text { algoritmalar } \\
\text { ve kullanıcı } \\
\text { arastırmaları }\end{array}$ & \begin{tabular}{|l|} 
Teorik \\
Tartış- \\
ma \\
\\
\end{tabular} & - & - & $\begin{array}{l}\text { Problem } \\
\text { ortaya } \\
\text { koyan }\end{array}$ \\
\hline 18 & $\begin{array}{l}\text { Digital Jour- } \\
\text { nalism Vol } \\
8 / 1 \text { - } 2020\end{array}$ & $\begin{array}{l}\text { Mapping the } \\
\text { Mobile DNA } \\
\text { of News. Un- } \\
\text { derstanding } \\
\text { Incidental and } \\
\text { Serendipitous } \\
\text { Mobile News } \\
\text { Consumption }\end{array}$ & Kullanıcı & $\begin{array}{l}\text { Kavramlar } \\
\text { üzerinden } \\
\text { tartsşımış: } \\
\text { haber } \\
\text { tüketimi, } \\
\text { algoritmalar, } \\
\text { demokratik } \\
\text { toplum }\end{array}$ & \begin{tabular}{|l|} 
Karma \\
yöntem \\
(derin- \\
leme- \\
sine \\
görüş- \\
me ve \\
içerik \\
analizi) \\
\end{tabular} & $\begin{array}{l}20 \text { kişi ile } \\
\text { derinle- } \\
\text { mesine } \\
\text { görüşme }\end{array}$ & Belçika & \begin{tabular}{|l|} 
Problem \\
olmadığı \\
sonucuna \\
ulaşan
\end{tabular} \\
\hline 19 & $\begin{array}{l}\text { Digital Jour- } \\
\text { nalism Vol } \\
8 / 4 \text { - } 2020\end{array}$ & $\begin{array}{l}\text { Man vs. Machi- } \\
\text { ne? The Impact } \\
\text { of Algorithm } \\
\text { Authorship on } \\
\text { News Credi- } \\
\text { bility }\end{array}$ & Kullanıcı & $\begin{array}{l}\text { Kavramlar } \\
\text { üzerinden } \\
\text { tartşılmış: } \\
\text { otomatize } \\
\text { gazetecilik } \\
\text { ve güveni- } \\
\text { lirlik }\end{array}$ & Anket & $\begin{array}{l}420 \text { kat- } \\
\text { lımcı ile } \\
\text { anket }\end{array}$ & Singapur & \begin{tabular}{|l|} 
Problem \\
olmadığı \\
sonucuna \\
ulaşan
\end{tabular} \\
\hline
\end{tabular}




\begin{tabular}{|c|c|c|c|c|c|c|c|c|}
\hline 20 & $\begin{array}{l}\text { Digital Jour- } \\
\text { nalism Vol } \\
8 / 5 \text { - } 2020\end{array}$ & $\begin{array}{l}\text { Paying Attenti- } \\
\text { on to Attenti- } \\
\text { on: A Concep- } \\
\text { tual Framework } \\
\text { for Studying } \\
\text { News Reader } \\
\text { Revenue } \\
\text { Models Related } \\
\text { to Platforms }\end{array}$ & $\begin{array}{l}\text { Üretim } \\
\text { aşaması/ } \\
\text { çalışma } \\
\text { pratikleri }\end{array}$ & $\begin{array}{l}\text { Kavramlar } \\
\text { üzerinden } \\
\text { tartışılmış: } \\
\text { algoritmalar, } \\
\text { dikkat eko- } \\
\text { nomisi }\end{array}$ & $\begin{array}{l}\text { Teorik } \\
\text { Tartiş- } \\
\text { ma }\end{array}$ & - & - & $\begin{array}{l}\text { Problem } \\
\text { ortaya } \\
\text { koyan }\end{array}$ \\
\hline 21 & $\begin{array}{l}\text { Digital Jour- } \\
\text { nalism Vol } \\
8 / 5 \text { - } 2020\end{array}$ & $\begin{array}{l}\text { The Unified } \\
\text { Framework of } \\
\text { Media Diver- } \\
\text { sity: A Systema- } \\
\text { tic Literature } \\
\text { Review }\end{array}$ & Betimsel & $\begin{array}{l}\text { Kavramlar } \\
\text { üzerinden } \\
\text { tartışılmış: } \\
\text { medya çeşit- } \\
\text { liliği, algorit- } \\
\text { malar }\end{array}$ & $\begin{array}{l}\text { Me- } \\
\text { ta-ana- } \\
\text { liz }\end{array}$ & $\begin{array}{l}1999-2018 \\
\text { yılları } \\
\text { arasında } \\
\text { yayınlan- } \\
\text { mış medya } \\
\text { çeşitliliği } \\
\text { kavramını } \\
\text { içeren } 206 \\
\text { çalışma in- } \\
\text { celenmis. } \\
\end{array}$ & - & $\begin{array}{l}\text { Problem } \\
\text { ortaya } \\
\text { koyan ve } \\
\text { çözüm } \\
\text { öneren }\end{array}$ \\
\hline 22 & $\begin{array}{l}\text { Digital Jour- } \\
\text { nalism Vol } \\
8 / 6 \text { - } 2020\end{array}$ & $\begin{array}{l}\text { Combating } \\
\text { Disinformation } \\
\text { on Social Me- } \\
\text { dia: Multilevel } \\
\text { Governance } \\
\text { and Distributed } \\
\text { Accountability } \\
\text { in Europe }\end{array}$ & Betimsel & $\begin{array}{l}\text { Kavramlar } \\
\text { üzerinden } \\
\text { tartışılmış: } \\
\text { dezenfor- } \\
\text { masyon, } \\
\text { sahte haber. }\end{array}$ & $\begin{array}{l}\text { Teorik } \\
\text { Tartış- } \\
\text { ma }\end{array}$ & $\begin{array}{l}\text { Fransa, } \\
\text { Ingiltere, } \\
\text { Almanya }\end{array}$ & $\begin{array}{l}\text { Avrupa } \\
\text { geneli } \\
\text { (ağırlıklı } \\
\text { olarak } \\
\text { Bat } \\
\text { Avrupa } \\
\text { ülkeleri) }\end{array}$ & $\begin{array}{l}\text { Problem } \\
\text { ortaya } \\
\text { koyan ve } \\
\text { çözüm } \\
\text { öneren }\end{array}$ \\
\hline 23 & $\begin{array}{l}\text { Digital Jour- } \\
\text { nalism Vol } \\
8 / 7 \text { - } 2020\end{array}$ & $\begin{array}{l}\text { Computational } \\
\text { News Disco- } \\
\text { very: Towards } \\
\text { Design Con- } \\
\text { siderations } \\
\text { for Editorial } \\
\text { Orientation } \\
\text { Algorithms in } \\
\text { Journalism } \\
\end{array}$ & $\begin{array}{l}\text { Üretim } \\
\text { aşaması/ } \\
\text { çalışma } \\
\text { pratikleri } \\
+ \text { Kulla- } \\
\text { nıcı }\end{array}$ & $\begin{array}{l}\text { Kavramlar } \\
\text { üzerinden } \\
\text { tartışılmış: } \\
\text { eşik bekçiliği }\end{array}$ & $\begin{array}{l}\text { Derin- } \\
\text { leme- } \\
\text { sine } \\
\text { görüş- } \\
\text { me }\end{array}$ & \begin{tabular}{|l|} 
Toplam \\
18 kişiden \\
oluşan \\
yazılımcı \\
ve kullanı- \\
cılar
\end{tabular} & $A B D$ & $\begin{array}{l}\text { Problem } \\
\text { ortaya } \\
\text { koyan ve } \\
\text { çözüm } \\
\text { öneren }\end{array}$ \\
\hline 24 & $\begin{array}{l}\text { Digital Jour- } \\
\text { nalism Vol } \\
8 / 9-2020\end{array}$ & \begin{tabular}{|l|} 
Taming the \\
News Feed \\
on Facebook: \\
Understanding \\
Consumptive \\
News Feed \\
Curation th- \\
rough a Social \\
Cognitive Pers- \\
pective
\end{tabular} & Kullanıcı & $\begin{array}{l}\text { Sosyo-biliş- } \\
\text { sel kuram }\end{array}$ & Anket & $\begin{array}{l}3413 \mathrm{Fa}- \\
\text { cebook } \\
\text { kullanıcı- } \\
\text { sıyla online } \\
\text { anket }\end{array}$ & ABD & $\begin{array}{l}\text { Problem } \\
\text { ortaya } \\
\text { koyan }\end{array}$ \\
\hline 25 & $\begin{array}{l}\text { Digital Jour- } \\
\text { nalism Vol } \\
8 / 9-2020\end{array}$ & $\begin{array}{l}\text { User Perspe- } \\
\text { ctives on the } \\
\text { News Persona- } \\
\text { lisation Pro- } \\
\text { cess: Agency, } \\
\text { Trust and Uti- } \\
\text { lity as Building } \\
\text { Blocks }\end{array}$ & Kullanıcı & $\begin{array}{l}\text { Kavramlar } \\
\text { üzerinden } \\
\text { tartşılmış: } \\
\text { kişiselleşti- } \\
\text { rilmiş haber- } \\
\text { ler, algorit- } \\
\text { malar, haber } \\
\text { güvenilirliği } \\
\end{array}$ & \begin{tabular}{|l} 
Odak \\
grup \\
görüş- \\
mesi
\end{tabular} & $\begin{array}{l}\text { Toplam } 24 \\
\text { haber oku- } \\
\text { yucusuyla } \\
4 \text { farklı } \\
\text { odak grup } \\
\text { görüşmesi. }\end{array}$ & Almanya & $\begin{array}{l}\text { Problem } \\
\text { ortaya } \\
\text { koyan }\end{array}$ \\
\hline
\end{tabular}




\begin{tabular}{|c|c|c|c|c|c|c|c|c|}
\hline 26 & $\begin{array}{l}\text { Journalism } \\
\text { Studies Vol } \\
20 / 5 \text { - } 2019\end{array}$ & $\begin{array}{l}\text { The New Gate- } \\
\text { keepers: } \\
\text { An Institutio- } \\
\text { nal-level View } \\
\text { of Silicon Valley } \\
\text { and the Disrup- } \\
\text { tion of Journa- } \\
\text { lism }\end{array}$ & $\begin{array}{l}\text { Üretim } \\
\text { aşaması/ } \\
\text { çalışma } \\
\text { pratikleri }\end{array}$ & $\begin{array}{l}\text { Kavramlar } \\
\text { üzerinden } \\
\text { tartsşılmış: } \\
\text { kişiselleşti- } \\
\text { rilmiş haber- } \\
\text { ler, algorit- } \\
\text { malar, eşik } \\
\text { bekçiliği }\end{array}$ & $\begin{array}{l}\text { İçerik } \\
\text { analizi }\end{array}$ & \begin{tabular}{|l|}
22 kişiden \\
oluşan \\
haber \\
editörü ve \\
teknoloji \\
şirketleri- \\
nin yöne- \\
ticilerinin \\
söylemleri.
\end{tabular} & ABD & $\begin{array}{l}\text { Problem } \\
\text { ortaya } \\
\text { koyan }\end{array}$ \\
\hline 27 & $\begin{array}{l}\text { Journalism } \\
\text { Studies Vol } \\
20 / 10 \text { - } 2019\end{array}$ & \begin{tabular}{|l|} 
Journalism \\
Reconfigured: \\
Assessing hu- \\
man-machine \\
relations and \\
the autono- \\
mous power of \\
automation in \\
news produ- \\
ction
\end{tabular} & $\begin{array}{l}\text { Üretim } \\
\text { aşaması/ } \\
\text { çalışma } \\
\text { pratikleri }\end{array}$ & $\begin{array}{l}\text { Aktör Ağ } \\
\text { Kuramı }\end{array}$ & $\begin{array}{l}\text { Derin- } \\
\text { leme- } \\
\text { sine } \\
\text { görüş- } \\
\text { me }\end{array}$ & \begin{tabular}{|l}
15 haber \\
editörüyle \\
derinle- \\
mesine \\
görüşme
\end{tabular} & Singapur & $\begin{array}{l}\text { Problem } \\
\text { ortaya } \\
\text { koyan }\end{array}$ \\
\hline 28 & $\begin{array}{l}\text { Journalism } \\
\text { Studies Vol } \\
21 / 7 \text { - } 2020\end{array}$ & \begin{tabular}{|l} 
(What) Can \\
Journalism Stu- \\
dies Learn from \\
Supervised \\
Machine Lear- \\
ning?
\end{tabular} & Betimsel & $\begin{array}{l}\text { Kavramlar } \\
\text { üzerinden } \\
\text { tartışılmış: } \\
\text { niceliksel } \\
\text { yöntem, } \\
\text { algoritma- } \\
\text { lar, makine } \\
\text { öğrenmesi } \\
\end{array}$ & $\begin{array}{l}\text { Teorik } \\
\text { Tartiş- } \\
\text { ma }\end{array}$ & - & - & $\begin{array}{l}\text { Problem } \\
\text { ortaya } \\
\text { koyan ve } \\
\text { çözüm } \\
\text { öneren }\end{array}$ \\
\hline 29 & $\begin{array}{l}\text { Journalism } \\
\text { Studies Vol } \\
21 / 7 \text { - } 2020\end{array}$ & \begin{tabular}{|l|} 
Agent-based \\
Testing: An \\
Automated \\
Approach \\
toward Artifici- \\
al Reactions to \\
Human Beha- \\
vior
\end{tabular} & Betimsel & $\begin{array}{l}\text { Kavramlar } \\
\text { üzerinden } \\
\text { tartşılmış: } \\
\text { kişiselleş- } \\
\text { tirilmiş } \\
\text { haberler, } \\
\text { algoritmalar, } \\
\text { niceliksel } \\
\text { ve niteliksel } \\
\text { araştirma } \\
\text { teknikleri } \\
\end{array}$ & $\begin{array}{l}\text { Teorik } \\
\text { Tartiş- } \\
\text { ma }\end{array}$ & - & - & $\begin{array}{l}\text { Problem } \\
\text { ortaya } \\
\text { koyan ve } \\
\text { çözüm } \\
\text { öneren }\end{array}$ \\
\hline 30 & $\begin{array}{l}\text { Journalism ve } \\
\text { Mass Com- } \\
\text { munication } \\
\text { Quarterly } \\
96 / 1 \text { - } 2019\end{array}$ & $\begin{array}{l}\text { Libel by Algo- } \\
\text { rithm? } \\
\text { Automated } \\
\text { Journalism and } \\
\text { the Threat of } \\
\text { Legal Liability }\end{array}$ & $\begin{array}{l}\text { Üretim } \\
\text { aşaması/ } \\
\text { çalışma } \\
\text { pratikleri }\end{array}$ & $\begin{array}{l}\text { Kavramlar } \\
\text { üzerinden } \\
\text { tartşılmış: } \\
\text { robot gaze- } \\
\text { tecilik, yasal } \\
\text { yükümlülük- } \\
\text { ler, algorit- } \\
\text { mik hatalar } \\
\end{array}$ & $\begin{array}{l}\text { Teorik } \\
\text { Tartiş- } \\
\text { ma }\end{array}$ & - & $A B D$ & $\begin{array}{l}\text { Problem } \\
\text { ortaya } \\
\text { koyan ve } \\
\text { çözüm } \\
\text { öneren. }\end{array}$ \\
\hline
\end{tabular}




\begin{tabular}{|c|c|c|c|c|c|c|c|}
\hline 31 & \begin{tabular}{|l|} 
Journalism ve \\
Mass Com- \\
munication \\
Quarterly \\
$96 / 1$ - 2019
\end{tabular} & \begin{tabular}{|l|} 
Can an Algo- \\
rithm Reduce \\
the Perceived \\
Bias of News? \\
Testing the Ef- \\
fect of Machine \\
Attribution on \\
News Readers' \\
Evaluations of \\
Bias, Anthropo- \\
morphism, and \\
Credibility
\end{tabular} & Kullanıcı & $\begin{array}{l}\text { Kavramlar } \\
\text { üzerinden } \\
\text { tartşılmış: } \\
\text { haberde } \\
\text { güvenilirlik, } \\
\text { haberde } \\
\text { yönlendir- } \\
\text { me, algorit- } \\
\text { malar }\end{array}$ & Anket & $\begin{array}{l}612 \text { okuyu- } \\
\text { cuya onli- } \\
\text { ne anket. }\end{array}$ & \begin{tabular}{|l|} 
Problem \\
olmadığı \\
sonucuna \\
ulaşan
\end{tabular} \\
\hline
\end{tabular}

Makalelerin önemli bir bölümünün odağının dijital gazetecilikte kullanılan algoritmaların üretim aşaması ve çalışma pratikleri (\%45) ile kullanııılar (\%29) olduğu saptanmıştır. Bu durumun temel nedenlerinden biri, algoritmaların gazetecilik alanında yeni bir teknolojik girdi olarak karşımıza çıkmasıdır. Ayrıca çalışmalarda hem üretim aşamasına hem de kullanıcılara odaklanılabildiği görülmüştür (\%7). Çalışmalarda algoritmaların gazetecilikteki kullanımlarının geleceği üzerine de değerlendirmelerde bulunulduğu görülmüştür. Örneğin kullanıcılara odaklanan çalışmalarında Lewis ve diğerleri (2019: 75) gazeteciliğin geleceğinde robot gazeteciliğin bir demirbaş hâline geleceğini, bu nedenle de gazetecilik ve medya hukuku akademisyenlerinin yanı sıra haber odalarında algoritma süreçlerini yöneten profesyonellere intiyaç duyulacağını belirtmektedirler. Bu nedenle de bu tür teknolojilerin hem yasal hem de toplumsal ve etik sonuçları üzerinde düşünmek önemlidir.

Kullanıcıların algoritmalar tarafindan oluşturulan ya da dağıtılan içeriklere yönelik tutumu ve onları tüketme ya da alımlama biçimleri de araştırmalarda incelenen bir diğer odaktır. Örneğin Haim (2020: 896), algoritmaya dayalı içerik ortamlarında içerik sunumundaki kullanıcı farklııklarının sistematik olarak değerlendirilmesine odaklanmıştr. Monzer ve diğerleri (2020: 1153) ise haber önerilerine duyulan güveni artırmak için haber medyasının kullanıcıları neden belirli bilgileri gördükleri (veri koruma yasalarından takip edilen bir gereklilik), bu bilgileri kimin seçtiği ve hangi mesleki veya etik standartların yürürlükte olduğu konusunda bilgilendirmesi gerektiği sonucuna ulaşmışlardır. Ayrıca incelenen çalışmalarda betimsel çalışmaların (\%13), metin analizinin (\%3) ve hem metin analizi hem de kullanıcı odağı içeren çalışmaların (\%3) sınırlı olduğu saptanmıştır.

Az sayıda çalışmanın belirli ve sabit bir kuram etrafinda gerçekleştirildiği görülmüş; bu çalışmalarda aktör ağ kuramı, sosyal-bilişsel kuram ve Bourdieu'nun alan kuramının kullanıldığı ortaya çıkmıştı. Wu ve diğerleri (2019b), gazetecilik alanına giren teknolojik firmalar tarafindan sağlanan otomasyonun gazeteciliği nasıl sert şekillerde dönüştürebileceğini araştırmak için Bourdieu'nun alan teorisine 
başvurmuşlardır. Çalışmalarında, yapı ve failliği uzlaştırarak, toplumsal yapıların gazetecilik alanının mantığını ve temsilcilerin otomasyonu benimseme davranışını şekillendirdiğini ve aktörlerin zaman içinde yapıları yeniden şekillendirir hâle geldiklerini belirtmişlerdir. Gerçekleştirdikleri derinlemesine görüşmeler sonucunda, otomasyonun benimsenmesinin uzun vadede gazetecilik alanının özerk gücünü artırmasına karşın gazetecilerin tutumlarındaki farklılıklar nedeniyle alanın bir mücadele alanı olarak kaldığını ortaya koymuşlardır. Belirli bir kuramı benimsemeyen diğer çalışmalar ise sabit bir kuram yerine kavramlar etrafinda analizler gerçekleştirmiştir. Bu kapsamda, söz konusu çalışmalarda en çok başvurulan kavramlar ve konular; haberde yönlendirme ve demokrasi tartışmaları, kişiselleştirilmiş haber teknolojisi ve filtre balonları, insan-makine iletişimi, gazeteciliğin geleceği, otomatize gazetecilik, eşik bekçiliği ve dikkat ekonomisi olmuştur.

Çalışmaların çoğunlukla ampirik araştırmalara dayandığı görülmüştür (\%62). Kuramsal tartışmaya dayalı çalışmalar ise daha azınlıktadır (\%38). İncelenen makalalelerde sık kullanılan teknikler ise anket (\%19), derinlemesine görüşme (\%16) ve içerik analizidir (\%13). Az sayıda çalışmada ise odak grup (\%3) ve meta-analizi (\%3) kullanılmıştır. Büyük veri teknolojisine paralel olacak şekilde çok sayıda kullanıcının web arama sonuçlarını örneklem olarak kabul eden çalışmalar yeni bir kategori olarak karşımıza çıkmaktadır. Yine internet teknolojilerindeki gelişmelerin de etkisiyle veri toplamanın kolaylaşması nedeniyle anketlerde örneklem sayısının oldukça fazla olduğu görülmüştür. Örneğin, Thurman ve diğerleri (2019) 53.314 katılımcı ile bir anket çalışması gerçekleştirmiştir. Derinlemesine görüşme ve odak grup çalışmalarının ise nitel analiz desenine uygun düşecek şekilde sınırIı sayıda katılımcıyla gerçekleştirildiği bulgulanmıştır. Diakopoulos (2020) üretim aşamasına odaklandığı çalışmasında 18 kişi ile, Wu ve diğerleri (2019a) ise 15 haber editörü ile derinlemesine görüşmeler gerçekleştirmiştir.

Araştırmaların gerçekleştiği yer ve örneklem seçiminin çoğunlukla (\%52) ABD ve Avrupa merkezli olduğu saptanmıştır. Bu durumun temel nedeni, algoritma teknolojilerinin bu coğrafyalardan doğması ve erken benimseyenlerin de (early adopters) bu ülkelerde yerleşik olmalarıdır.

Algoritma ve dijital gazetecilikle ilgili makalelerin önemli bir bölümünün teknoloji ve teknolojinin kullanım pratiklerine yoğunlaşırken etik konusuna yeterince değinmemeleri dikkat çekmektedir. Incelenen çalışmaların \%48'i algoritmalara ilişkin problemler ortaya koyarken \%36'sı hem problem ortaya koymakta hem de bu problemlere yönelik çözümler önrmektedir. Incelenen çalışmaların \%16'sında ise algoritmaların kullanımına ya da işleyişine yönelik bir problem olmadığı belirtilmektedir. İncelenen makalelerin çoğunda algoritmalara ilişkin çeşitli problem- 
lerden bahsediliyor olsa da bu problemlerin çok azının (\%19) etik sorunlarla ilgili olduğu açığa çıkmıştır.

Dijital gazetecilik bağlamında algoritma etiğine değinen ve çözüm öneren az sayıda çalışma olduğu görülmektedir. Buna karşın algoritma etiğine dayanan çalışmalar, etik sorunların ciddi sorunlara neden olabileceğini ortaya koymaktadırlar. Örneğin, Robinson ve diğerleri (2019: 371) dijital medya aracılığıyla, gazetecilik etiği ile ilgili soruların yeni ve önemli boyutlar kazandığını, dijital medya aracılığıyla özel yerler olduğunu düşündüğümüz dijital platformlarda cesaretsiz veya tehlike altında hissedebileceğimizi vurgulamaktadırlar. Stray (2019: 1086-1093) ise çeşitli araştırmalar için algoritmaları kullanan haber kuruluşlarının, insanları işlemedikleri suçlardan bile yargılanabilir hâle getirebileceğini öngörmektedir. Örneğin, kara para aklama şüphesi bulmak için kamu kayıtlarını incelemek için algoritmaları kullanan bir haber kuruluşu, yanlış bir şekilde (çıkarımlarının diğer \%99'u doğru olsa bile) herhangi birinin suç teşkil eden bir faaliyete karıştı̆̆ını ileri sürerek sadece gazetecilik etiğini ciddi bir şekilde ihlal etmekle kalmayıp aynı zamanda bir hakaret davasına da neden olabilmektedir. Bodó (2019: 1058) ise algoritmik gazetecilik nedeniyle gizlilik, veri koruma ve editoryal bağımsızlık etrafinda yasal ve etik sorunlar ortaya çıktığı sonucuna ulaşmıştır.

Gazetecilik alanına ilişkin olarak algoritmalara dayalı etik sorunlardan bahseden çalışmalarda, etik sorunların çözülebilmesi için yasal düzenlemeler olabileceği, makine öğrenmesi teknolojisinin kullanılabileceği, insan kontrolünün olması gerektiği, kullanıcıların algoritma seçimlerine ilişkin bilgilendirilebileceği gibi fikirler ortaya atılmıştır. Helberger (2019: 1003), kullanıcıları aktif olarak uyarmak gerektiğini vurgulayarak bilgi, eğitim ve manipülasyon arasında ince çizgi olduğunu ve medyanın filtre balonlarını "patlatma" sorumluluğunun bulunduğunu ifade etmektedir. Ayrıca yayınlanan tüm çıkarımlarda esasen kusursuz doğruluğun şart olduğunu, bu nedenle de algoritma çıktılarına yönelik insan kontrolünün gerektiğini belirtmektedir. Lewis ve diğerleri (2019) ise haber yazım botlarının geliştirilirken ve kullanılırken yasal yükümlülüklerin sıklıkla göz ardı edildiği vurgulamakta ve bu anlamda yasal olarak göz önünde bulundurulması gereken iki temel nokta üzerinde durmaktadırlar: Algoritmalar tarafindan yazılan haberlerde iftira bulunması durumu ve hatalı içerik üretilmesi durumunda diğer algoritma üreticileri tarafindan yapılan savunmaların haber kuruluşları açısından kullanışlı olmaması. Araştırmada bu özel durumlar için Amerikan yasalarından yola çıkarak birtakım hukuki öneriler sunulmuştur (Lewis vd., 2019). Bir başka çalışmada ise BBC'nin okuyucularıyla etkileşim amacıyla kullandığı haber botlarının verimliliği test edilmiştir. Haber botlarının son derece temel düzeyde ve basit içerikler üretebildiği, 
ürettiği metinlerin kişiselleştirilmiş değil, genel okuyucuya hitap edebildiği sonucuna ulaşılmıştır. Öneri olarak kişiselleştirilmiş içerikler üretebilmesi ve okuyucuyla daha verimli bir diyalog kurulabilmesi için makine öğrenmesi teknolojisinin kullanılması gerektiği belirtilmiştir (Jones ve Jones, 2019). Monzer ve diğerleri (2020: 1153) ise haber önerilerine duyulan güveni artrrmak için medya kuruluşunun kullanıcıları neden belirli bilgileri gördükleri bu bilgileri kimin seçtiği ve hangi mesleki veya etik standartların yürürlükte olduğu konusunda bilgilendirmesinin etik sorunları aşmada yararlı olacağı sonucuna ulaşmışlardır.

\section{Sonuç}

Bu çalışmada algoritmalar ve gazetecilik etiği ile ilgili akademik makaleler incelenmiştir. Bu kapsamda, konunun mevcut dijital gazetecilik çalışmalarındaki güncel, metodolojik ve teorik eğilimlerinin belirlenmesi amaçlanmıştr. Böylece algoritmalarla ilgili araştırma gündeminin örüntüleri, dijital gazetecilik etiğiyle ilişkili olarak ele alınmıştır. Algoritmaların gazetecilikteki etik sorunlarının genel bir tespitini yapmak adına, alanda önde gelen üç dergi: Digital Journalism, Journalism Studies ve Journalism \& Mass Communication Quarterly incelenmiştir. Bu dergilerin 2019 ve 2020 yıllarının tüm sayılarında yayımlanmış makaleler arasından algoritma ile ilgili çalışmalara odaklanılmıştır. Gazetecilik alanında önde gelen bu dergilerde algoritmalara ilişkin çalışmalara alanda farkındalık oluşturacak kadar yer verilmediği görülmüştür. Geleceğin gazeteciliği açısından gittikçe daha da önemli olmaya devam edecek olan algoritmalara, gazetecilik çalışmalarında bu kadar az yer verilmesi konunun ihmal edildiğini düşündürmektedir. Algoritmalar ile ilgili az sayıda çalışmanın çok azında ise etik sorunlara değinildiği anlaşılmıştır.

Etik sorunlar, gazetecilik mesleği, dolayısıyla da gazetecilik disiplini açısından da henüz çözülememiş sorunlardandır. İnsanın etkinliğini azaltarak özellikle haber üretim süreci açısından çeşitli kolaylıklar sağlayan algoritmalar, daha önceden mevcut olmayan etik sorunlar yaratmaktadırlar. Buna karşın gazetecilik ile ilgili alandaki önde gelen dergilerde bu konuya çok az yer verilmiştir. Çalışmalarda, gazetecilikte kullanılan algoritmalar ile ilişkili olarak etik sorunlara yeterince değinilmemesinin geleceğin gazeteciliğini belirsizliklerle dolu daha güvensiz bir mecraya dönüştüreceği düşünülmektedir.

Algoritma etiği ile ilgili sınırlı sayıda çalışmada ise algoritmalara dayalı etik ihlallerin, insanların tehlike altında hissetmeleri ya da suçsuz yere yargılanmaları gibi ciddi sorunlara neden olabileceğini ortaya koymuştur. Ayrıca gazetecilik alanına ilişkin olarak algoritmalara dayalı etik sorunları inceleyen çalışmalarda, etik sorunların çözülebilmesi için çeşitli yasal düzenlemeler olabileceği, makine öğrenmesi teknolo- 
jisinin kullanılabileceği, insan kontrolünün olması gerektiği, kullanıcıların algoritma seçimlerine ilişkin bilgilendirilebileceği gibi öneriler sunulmuştur.

Sonuç olarak algoritmaların kullanıcıların failliğinini tamamen ortadan kaldıran etkinliğinin, etik sorunlar yaratth̆̆ ve bu duruma yönelik henüz yeterli çözümlerin geliştirilemediği söylenebilir. Bu nedenle de hâlâ kullanıcıların karar verme mekanizmalarının etik sorunları çözmede etkin olabileceği düşünülmektedir. Buna karşın mahremiyet sorunlarını aşan, veri arama ve verinin kaynağına dayalı sorunları, algoritmik otorite sorunlarını aşan, verilerin kötüye kullanımını engelleyen, algoritmik nesnellik, şeffaflık ve hesapverebilirlik niteliklerini taşıyan daha farklı algoritmalar geliştirildikçe insanların karar verme noktasındaki etkinliğinin de azalabileceği düşünülebilir. Makine öğrenme teknolojisi de bu algoritmaların nesnelliği, şeffaflığı, hesapverebilirliği açısından olanaklar sağlayabilecektir. Ancak bu algoritmalar geliştirilinceye kadar yasal düzenlemeler, insan kontrolü ve kullanıcıların bilgilendirilmesi gibi yöntemlerle algoritmaların gazetecilik açısından kullanımı daha az etik soruna neden olur hâle getirilebilecektir.

\section{Kaynakça}

Ananny, M. (2016). Toward an ethics of algorithms: Convening, observation, probability, and timeliness. Science, Technology, \& Human Values, 41(1), 93-117.

Ananny, M., \& Crawford, K. (2018). Seeing without knowing: Limitations of the transparency ideal and its application to algorithmic accountability. New Media \& Society, 20(3), 973-989.

Anderson, C.W. (2011). Notas hacia un análisis del periodismo computacional (26 October, 2011). HIIG Discussion Paper Series No. 2012-1. Available at SSRN: https:// ssrn.com/abstract=2009292 o http://dx.doi.org/10.2139/ssrn.2009292

Binark, M. (2017). Algoritmaların yarattğı yankı odalarında siyasal katılımın olanaksızlığı. Varlık, 1317, 19-23.

Bodó, B. (2019). Selling news to audiences-a qualitative inquiry into the emerging logics of algorithmic news personalization in European quality news media. Digital Journalism, 7(8), 1054-1075.

Bodó, B., Helberger, N., Eskens, S., \& Möller, J. (2019). Interested in diversity: The role of user attitudes, algorithmic feedback loops, and policy in news personalization. Digital Journalism, 7(2), 206-229.

Bradshaw, P. (2014). “Data Journalism." içinde Ethics for Digital Journalists: Emerging Best Practices, Lawrie Zion ve David Craig, Routledge, New York and London, 202-220.

Burrell, J. (2016). How the machine "thinks": Understanding opacity in machine learning algorithms. Big Data \& Society, 3(1), 1-12. 
Carlson, M. (2014). The Robotic Reporter. Automated Journalism and the Redefinition of Labor, Compositional Forms, and Journalistic Authority. Digital Journalism 3 (3): 416-431. doi: 10.1080/21670811.2014.976412.

Carlson, M. (2015). The robotic reporter: automated journalism and the redefinition of labour, compositional forms, and journalistic authority. Digital journalism $3(3), 416-431$.

Carlson, M. (2018). Automating judgment? Algorithmic judgment, news knowledge, and journalistic professionalism. New Media \& Society, 20(5), 1755-1772.

Carlson, M. (2019). News algorithms, photojournalism and the assumption of mechanical objectivity in journalism. Digital Journalism, 7(8), 1117-1133.

Caswell, D. (2019). Structured journalism and the semantic units of news. Digital Journalism, 7(8), 1134-1156.

Cave, S., Nyrup, R., Vold, K., \& Weller, A. (2018). Motivations and risks of machine ethics. Proceedings of the IEEE, 107(3), 562-574.

De Grove, F., Boghe, K., \& De Marez, L. (2020). (What) Can Journalism Studies Learn from Supervised Machine Learning?. Journalism Studies, 21(7), 912-927.

Deuze, M. (2005). What is Journalism?: Professional Identity and Ideology of Journalists Reconsidered. Journalism 6 (4): 422-464.

Diakopoulos N. (2015). Algorithmic accountability: journalistic investigation of computational power structures. Digital Journalism 3(3): 398-415.

Diakopoulos, N. \& Michael K. (2017). Algorithmic Transparency in the News Media, Digital Journalism, 5:7, 809-828, DOI: 10.1080/21670811.2016.1208053.

Diakopoulos, N. (2020). Computational News Discovery: Towards Design Considerations for Editorial Orientation Algorithms in Journalism. Digital Journalism, 8(7), 945-967.

Digital Journalism, Erişim adresi: https://www.tandfonline.com/action/journallnformation?show=aimsScope\&journalCode=rdij20, Erişim tarihi: 04.03.2021

Dörr, K. N., \& Hollnbuchner, K. (2016). Ethical Challenges of Algorithmic Journalism. Digital Journalism. doi:10.1080/21670811.2016.1167612. edited by Lawrie Zion and David Craig, 202-219. New York: Routledge.

Ford, H., \& Hutchinson, J. (2019). Newsbots that mediate journalist and audience relationships. Digital Journalism, 7(8), 1013-1031.

Gillespie, T. (2014). The relevance of algorithms. In Gillespie T., Boczkowski P., \& Foot K., (Ed.) Media Technologies: Essays on Communication, Materiality, and Society (pp. 167- 194). Cambridge, MA: The MIT Press.

Grochowski J. R. \& Ornstein, C. (2016). Matching Industry Payments to Medicare Prescribing Patterns: An Analysis. ProPublica Whitepaper. https://static.propublica.org/projects/d4d/20160317-matching-industry-payments.pdf?22.

Guzman, A. L. (2019). Prioritizing the Audience's View of Automation in Journalism. Digital Journalism, 7(8), 1185-1190.

Haim, M. (2020). Agent-based Testing: An automated approach toward artificial reactions to human behavior. Journalism Studies, 21(7), 895-911.

Hansen, M., Roca-Sales, M., Keegan, J. \& King, G. (2017). Artificial Intelligence: Practice and Implications for Journalism. Brown Institute for Media Innovation and the Tow Center for Digital Journalism. 
Harambam J., Helberger N., van Hoboken J. (2018). Democratizing algorithmic news recommenders: how to materialize voice in a technologically saturated media ecosystem. Phil. Trans. R. Soc. A 376: 20180088.http://dx.doi. org/10.1098/rsta.2018.0088

Heald, D. (2006). Varieties of transparency. In C. Hood \& D. Heald (Eds.), Transparency: The key to better governance? (pp. 25-46). Oxford, U.K.: Oxford University Press.

Helberger, N. (2019). On the democratic role of news recommenders. Digital Journalism, 7(8), 993-1012.

Jagadish, H.V. (2016). Data Science Ethics. Erişim: https://courses.edx.org/courses/course-v1:MichiganX+DS101x+3T2016/course/

Jameel, T., Ali, R., \& Toheed, I. (2020, January). Ethics of Artificial Intelligence: Research Challenges and Potential Solutions. In 2020 3rd International Conference on Computing, Mathematics and Engineering Technologies (iCoMET) (pp. 1-6). IEEE.

Jones, B., \& Jones, R. (2019). Public service chatbots: Automating conversation with BBC News. Digital Journalism, 7(8), 1032-1053.

Jones, R., \& Jones, B. (2019). Atomising the news: The (in) flexibility of structured journalism. Digital Journalism, 7(8), 1157-1179.

Journalism \& Mass Communication Quarterly, Erişim adresi: https://journals.sagepub. com/aims-scope/JMQ, Erişim tarihi: 04.03.2021

Journalism Studies, Erişim adresi: https://www.tandfonline.com/action/journallnformation?show=aimsScope\&journalCode=rjos20, Erişim tarihi: 04.03.2021

Just, N., \& Latzer, M. (2017). Governance by algorithms: Reality construction by algorithmic selection on the Internet. Media, Culture \& Society, 39(2), 238-258. DOI: $10.1177 / 0163443716643157$.

Kearns, M., \& Roth, A. (2019). The ethical algorithm: The science of socially aware algorithm design. Oxford University Press.

Kraemer, F., Van Overveld, K., \& Peterson, M. (2011). Is there an ethics of algorithms?. Ethics and information technology, 13(3), 251-260.

Krippendorff, K. (1980). Validity in Content Analysis, içinde Ekkehard Mochmann (Ed.) Computerstrategien fur die Kommunikationsanalyse, Frankfurt/New York: Campus, Chapter 3, 69-112.

Leben, D. (2018). Ethics for robots: How to design a moral algorithm. Routledge.

Lewis, S. C., Guzman, A. L., \& Schmidt, T. R. (2019). Automation, journalism, and humanmachine communication: Rethinking roles and relationships of humans and machines in news. Digital Journalism, 7(4), 409-427.

Lewis, S. C., Sanders, A. K., \& Carmody, C. (2019). Libel by Algorithm? Automated Journalism and the Threat of Legal Liability. Journalism \& Mass Communication Quarterly, 96(1), 60-81. https://doi.org/10.1177/1077699018755983

Lewis, S. C., Sanders, A. K., \& Carmody, C. (2019). Libel by algorithm? Automated journalism and the threat of legal liability. Journalism \& Mass Communication Quarterly, 96(1), 60-81.

Lindén, C-G. (2017). Algorithms for journalism: the future of news work. The Journal of Media Innovations 4(1), 60-76. https://doi.org/10.5617/jmi.v4i1.2420 
Liu, B., \& Wei, L. (2019). Machine Authorship In Situ: Effect of news organization and news genre on news credibility. Digital Journalism, 7(5), 635-657.

Loecherbach, F., Moeller, J., Trilling, D., \& van Atteveldt, W. (2020). The unified framework of media diversity: A systematic literature review. Digital Journalism, 8(5), 605-642.

Lu, S. (2020). Taming the News Feed on Facebook: Understanding Consumptive News Feed Curation through a Social Cognitive Perspective. Digital Journalism, 8(9), 1163-1180.

Martin, K. (2019). Ethical implications and accountability of algorithms. Journal of Business Ethics, 160(4), 835-850.

McBride, Kelly ve Tom Rosenstiel (2014). "New Guiding Principles for a New Era of Journalism." İçinde The New Ethics of Journalism, edited by Kelly McBride and Tom Rosenstiel, 1-6. Thousand Oaks, CA: CQ Press.

Milosavljević, M., \& Vobič, I. (2019). Human still in the loop: Editors reconsider the ideals of professional journalism through automation. Digital journalism, 7(8), 1098-1116.

Mittelstadt, B. D., Allo, P., Taddeo, M., Wachter, S., \& Floridi, L. (2016). The ethics of algorithms: Mapping the debate. Big Data \& Society, 3(2), 2053951716679679.

Monzer, C., Moeller, J., Helberger, N., \& Eskens, S. (2020). User Perspectives on the News Personalisation Process: Agency, Trust and Utility as Building Blocks. Digital Journalism, 8(9), 1142-1162.

Myllylahti, M. (2020). Paying attention to attention: A conceptual framework for studying news reader revenue models related to platforms. Digital Journalism, 8(5), 567-575.

Narin, B. (2018). Kişiselleştirilmiş çevrim içi haber akışının yankı odası etkisi, filtre balonu ve siberbalkanizasyon kavramları çerçevesinde incelenmesi. Selçuk iletişim, 11(2), 232-251.

Newman, N. (2019). Journalism, Media and Technology Trends and Predictions 2019. Reuters Institute for the Study of Journalism.

Parmar, B., \& Freeman, R. E. (2016). Ethics and the algorithm. MIT Sloan Management Review, 58(1), 16.

Pasquale F. (2015). The Black Box Society. Cambridge, MA: Harvard University Press.

Puschmann, C. (2019). Beyond the bubble: Assessing the diversity of political search results. Digital Journalism, 7(6), 824-843.

Raymond, A. H., \& Shackelford, S. J. (2013). Technology, ethics, and access to justice: should an algorithm be deciding your case. Mich. J. Int'I L., 35, 485.

Richterich, A. (2018). The big data agenda: Data ethics and critical data studies (p. 154). University of Westminster Press.

Riffe, D., Lacy, S. ve Fico, F. (2005). Analyzing Media Messages: Using Quantitative Content Analysis In Research, New Jersey: Lawrence Erlbaum Associates, Inc.

Robinson, S., Lewis, S. C., \& Carlson, M. (2019). Locating the "Digital" in Digital Journalism Studies: Transformations in Research. Digital Journalism, 7(3), 368-377.

Russell, F. M. (2019). The new gatekeepers: an Institutional-level view of Silicon Valley and the disruption of journalism. Journalism Studies, 20(5), 631-648. 
Saurwein, F., \& Spencer-Smith, C. (2020). Combating disinformation on social media: Multilevel governance and distributed accountability in Europe. Digital Journalism, 8(6), 820-841.

Schreier, M. (2012). Qualitative content analysis in practice. Thousands Oaks, CA: Sage. Shearer, Matt, Basile Simon, and Clement Geiger (2014). "Datastringer: Easy Dataset Monitoring for Journalists." Proceedings Symposium on Computation + Journalism.

SJR, Scimago Journal \& Country Rank. Erişim adresi: https://www.scimagojr.com/aboutus.php, Erişim tarihi: 04.03.2021

Steiner, C. (2012) Automate This. New York: Portfolio/Penguin Press.

Stray, J. (2019). Making artificial intelligence work for investigative journalism. Digital Journalism, 7(8), 1076-1097.

Tandoc Jr, E. C., Yao, L. J., \& Wu, S. (2020). Man vs. machine? The impact of algorithm authorship on news credibility. Digital Journalism, 8(4), 548-562.

Thurman, N., Moeller, J., Helberger, N., \& Trilling, D. (2019). My friends, editors, algorith$\mathrm{ms}$, and I: Examining audience attitudes to news selection. Digital Journalism, 7(4), 447-469.

Túñez-Lopez, M.; C. Toural-Bran, C. Valdiviezo-Abad (2019). “Automation, bots and algorithms in newsmaking. Impact and quality of artificial journalism". Revista Latina de Comunicación Social, 74, 1411-1433 http://www.revistalatinacs. org/074paper/1391/74en.html DOI: 10.4185/RLCS-2019-1391en

Van Damme, K., Martens, M., Van Leuven, S., Vanden Abeele, M., \& De Marez, L. (2020). Mapping the mobile DNA of news. Understanding incidental and serendipitous mobile news consumption. Digital Journalism, 8(1), 49-68.

Waddell, T. F. (2019). Can an Algorithm Reduce the Perceived Bias of News? Testing the Effect of Machine Attribution on News Readers' Evaluations of Bias, Anthropomorphism, and Credibility. Journalism \& Mass Communication Quarterly, 96(1), 82-100. https://doi.org/10.1177/1077699018815891

Wu, S., Tandoc Jr, E. C., \& Salmon, C. T. (2019a). Journalism reconfigured: Assessing human-machine relations and the autonomous power of automation in news production. Journalism Studies, 20(10), 1440-1457.

Wu, S., Tandoc, E. C., \& Salmon, C. T. (2019b). A Field Analysis of Journalism in the Automation Age: Understanding Journalistic Transformations and Struggles Through Structure and Agency. Digital Journalism, 7(4), 428-446.

Young, M. L., \& Alfred H. (2014). From Mr. and Mrs. Outlier to Central Tendencies. Digital Journalism (online first), doi: 10.1080/21670811.2014.976409.

Zamith, R. (2019). Algorithms and Journalism, Oxford Research Encyclopedia of Communication, Subject: Journalism Studies Online Publication Date: Feb 2019, 1-21, DOI: 10.1093/acrefore/9780190228613.013.779

Zion, L. \& Craig D. (2014). Ethics for Digital Journalists. Emerging Best Practices. New York: Routledge. 


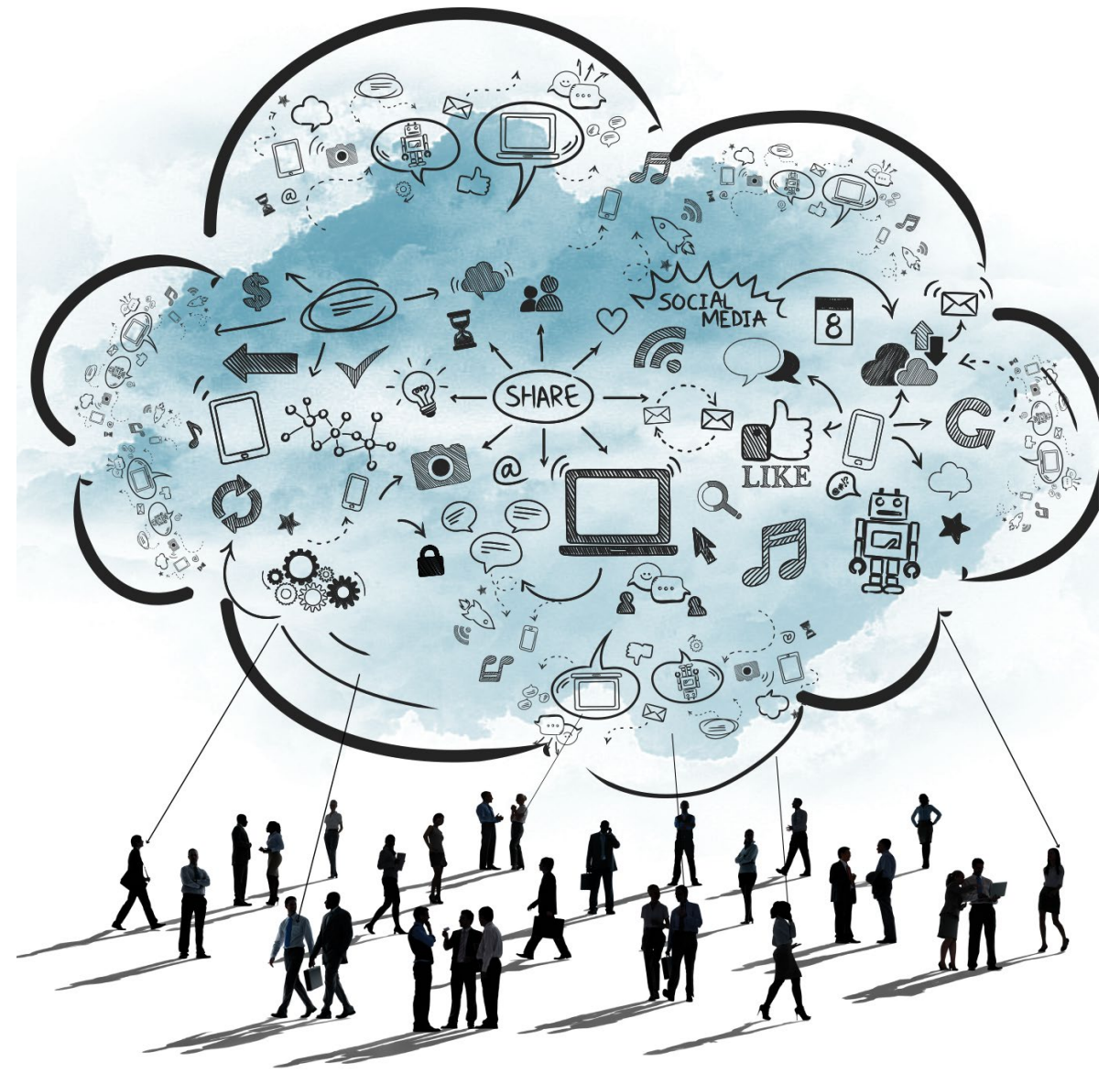

